\title{
O saxofone na música de câmara de Francisco Braga
}

\section{The saxophone in chamber music by Francisco Braga}

José de Carvalho Oliveira' Universidade Federal do Estado do Rio de Janeiro (PPGM-UNIRIO) josedecarvalhosax@gmail.com

Marco Túlio de Paula Pinto ${ }^{2}$ Universidade Federal do Estado do Rio de Janeiro (PPGM-UNIRIO) mtuliosax@gmail.com 


\section{Resumo}

A partir das obras Cantigas e danças dos pretos, para quarteto de saxofones (1905) e Diálogo Sonoro ao Luar - seresta para saxofone alto e bombardino em Dó, de Francisco Braga (s.d.), de forma sucinta, este trabalho traz à baila a representatividade do saxofone no repertório de câmara do compositor. Para os aspectos que dizem respeito às relações de Francisco Braga e o saxofone, utilizaremos como base os estudos de Oliveira (OLIVEIRA, Jane, 2019) e Macedo (2019). Quanto às interfaces estilísticas, como referência, os trabaIhos de Nascimento (2009), Soares (2015) e Cazes (2019).

Palavras-chave: Saxofone. Interfaces estilísticas. Escrita idiomática. Música brasileira. Francisco Braga.

\section{Abstract}

Starting from the works Cantiga $e$ Danças dos pretos - for quartet of saxophones (1905) and 'Diálogo Sonoro ao Luar' - seresta for alto saxophone and bombardino in C, by Francisco Braga (s.d.), in a succinct way, this article brings up the representativeness of the saxophone in Francisco Braga's chamber repertoire. For the aspects that concern the relations of Francisco Braga and the saxofone, we will use as a basis the studies of Oliveira (OLIVEIRA, Jane, 2019) and Macedo (2019). As for the stylistic interfaces, as a reference, the works of Nascimento (2009), Soares (2015) and Cazes (2019).

Keywords: Saxophone. Stylistic interfaces. Idiomatic writing. Brazilian music. Francisco Braga.

\footnotetext{
1 Natural de Matias Olímpio, Piaúi, José de Carvalho é doutorando em Música com pesquisa na área de Teoria e Prática da Interpretação pela Universidade Federal do Estado do Rio de Janeiro (UNIRIO). Mestre em Musicologia (Teoria e Análise Musical) pela Universidade de São Paulo, USP (pesquisa apoiada pela agencia de fomento CAPES). Graduado em Licenciatura em Música pelo Centro Universitário SantAnna, SP. É autor do livro Fantasia para saxofone soprano e pequena orquestra de Villa-Lobos: Aspectos Contextuais e Análise Estrutural do Primeiro Movimento (Ed. Diálogo Freiriano, 2021). Pertence ao grupo de pesquisa PAMVILLA (Perspectivas Analíticas para a Música de Villa-Lobos).

2 Doutor em música (Teoria e prática da interpretação) e Mestre em música (Práticas interpretativas) pela Universidade Federal do Estado do Rio de Janeiro (UNIRIO). Bacharel em saxofone pela Universidade Federal do Rio de Janeiro (UFRJ). Professor associado de saxofone na UNIRIO, atuando na graduação e pós-graduação (mestrado acadêmico, mestrado profissional e doutorado). Atualmente exerce a função de coordenador do Programa de Mestrado Profissional em Ensino das Práticas Musicais (PROEMUS) da UNIRIO.
} 


\section{Introdução}

Antônio Francisco Braga (1868-1945) figura entre os principais compositores da Primeira República Brasileira (1889-1930). Sua obra se destaca tanto na música sinfônica quanto nas formações camerísticas. Além da grande produção para banda, também possui destaque especial sua numerosa produção de hinos que, segundo Kiefer (1976), "na época lhe valeram o apelido de 'Chico dos hinos' - sendo o mais importante, o Hino à Bandeira Nacional (1906)" (KIEFER, 1976, p. 134). No Catálogo da exposição comemorativa do centenário de nascimento de Francisco Braga, publicado pela Biblioteca Nacional (1968), constam algumas dezenas de peças para música sacra (ave-marias, hinos, missas etc.). Ressalta-se, ainda, a produção de óperas e melodramas, 33 peças para canto e piano e cerca de 30 peças para piano solo.

Francisco Braga tem uma vasta produção para banda de música. É bastante provável a utilização do saxofone na orquestração dessas obras, levando-se em consideração a importância do instrumento nessa formação instrumental. No entanto, este estudo se restringirá apenas às composições que contêm o saxofone no contexto camerístico.

Quanto às questões analíticas, no que diz respeito aos processos harmônicos, estrutura formal e manipulação do material motívico e temático, de forma sucinta, como referência utilizaremos os estudos de Kostka et al. (2015). Em relação às interfaces estilísticas em Diálogo Sonoro ao Luar, como base, os trabalhos de Almeida (1942), Kiefer (1976), Nascimento (2009) e Soares (2015).

\section{Cantigas e danças dos pretos para quarteto de saxofones, de Fran- cisco Braga (1905)}

Ao iniciar a investigação sobre as relações de Francisco Braga com o saxofone, imaginou-se, inicialmente, que essa relação poderia ter se estabelecido, ou pelo menos se fortificado durante o período em que o compositor esteve na França como aluno do Conservatório Nacional Superior de Música e Dança de Paris, principal e primeira instituição de ensino a receber o curso de saxofone. No entanto, o período em que Francisco Braga esteve na França, como aluno do Conservatório de Paris (1890-1894), ocorreu justamente durante a extinção do curso de saxofone na referida instituição. O hiato refere-se ao espaço de 72 anos, estabelecido entre 1870 e 1942, o que indica a probabilidade de a correspondência do compositor com o instrumento ser anterior à sua estada na França. Mesmo assim, não se descarta a hipótese do contato de Braga com o instrumento no Conservatório de Paris, visto ser este o berço escolástico do saxofone.

Apesar da incipiência das informações em torno dessa questão, em referência à relação de Francisco Braga com o instrumento, existem outras duas hipóteses. A primeira, segundo a pesquisadora Soares (2015, p. 17), é que o contato do compositor com o saxofone aconteceu ainda na pré-adolescência, enquanto aluno da banda de música do Asilo dos Meninos Desvalidos do Rio de Janeiro, por ocasião de sua internação em 
1876 neste colégio; cujo objetivo era oferecer aos meninos desvalidos uma formação artística e de ofícios.

Conforme relata Soares (2015), o saxofone consta como um dos primeiros instrumentos com que Francisco Braga teve contato, "ao observar tanto entusiasmo no jovem, o Mestre Martins, regente da banda, convidou-o para dela fazer parte e lhe ensinou saxofone e requinta" (SOARES, 2015, p. 17). A segunda hipótese é que o contato tenha acontecido mesmo na banda do colégio, conforme relata Soares (2015), no entanto, não como aprendiz de saxofone. Braga teria iniciado na banda "tocando 'sax-horn' em mi bemol, depois requinta e, por fim, clarineta", conforme aponta a pesquisadora Oliveira (OLIVEIRA, Jane, 2019, p.1).

Em relação ao idiomatismo de Francisco Braga na escrita para o saxofone, além de ter tocado o instrumento e da experiência como regente, na condição de compositor, Francisco Braga dedicou grande parte de sua obra às bandas de música, o que provavelmente lhe proporcionou fluência e conhecimento das variantes timbrísticas da tessitura do instrumento, como também o conhecimento do resultado de combinações do timbre do saxofone com instrumentos de sopro que compõem a banda de música.

No que tangencia a utilização do instrumento na música de câmara de Francisco Braga, o compositor recorreu ao saxofone em duas ocasiões: na obra Cantigas e danças dos pretos, para quarteto de saxofones (soprano, alto, tenor e barítono) (1905) e Diálogo Sonoro ao Luar, para bombardino em Dó e saxofone alto (s.d.). Cronologicamente, foi em Cantigas e danças dos pretos (1905) que Francisco Braga utilizou pela primeira vez o instrumento em sua obra camerística, como música incidental no melodrama O contratador de diamantes (1905).

Outra peculiaridade recém-descoberta em torno desta peça refere-se ao título. No catálogo de obras de Francisco Braga (1968), consta como Cantigas e danças dos pretos para quarteto de saxofones (1905), porém, no manuscrito encontrado em abril de 2018, no arquivo da Banda Sinfônica do Corpo de Bombeiros do Rio de Janeiro (OLIVEIRA, José, 2019, p. 36), há uma parte para um noneto de saxofones, em vez de um quarteto como consta no catálogo - sendo dois saxofones sopranos, dois altos, dois tenores, dois barítonos e um sax baixo.

Aparentemente, o que levou o organizador do catálogo de 1968 a se referir à obra como um quarteto, foi o fato de a partitura se apresentar em quatro pautas e de não ter levado em conta os divisi, conforme demonstram as Fig. 1-4. 


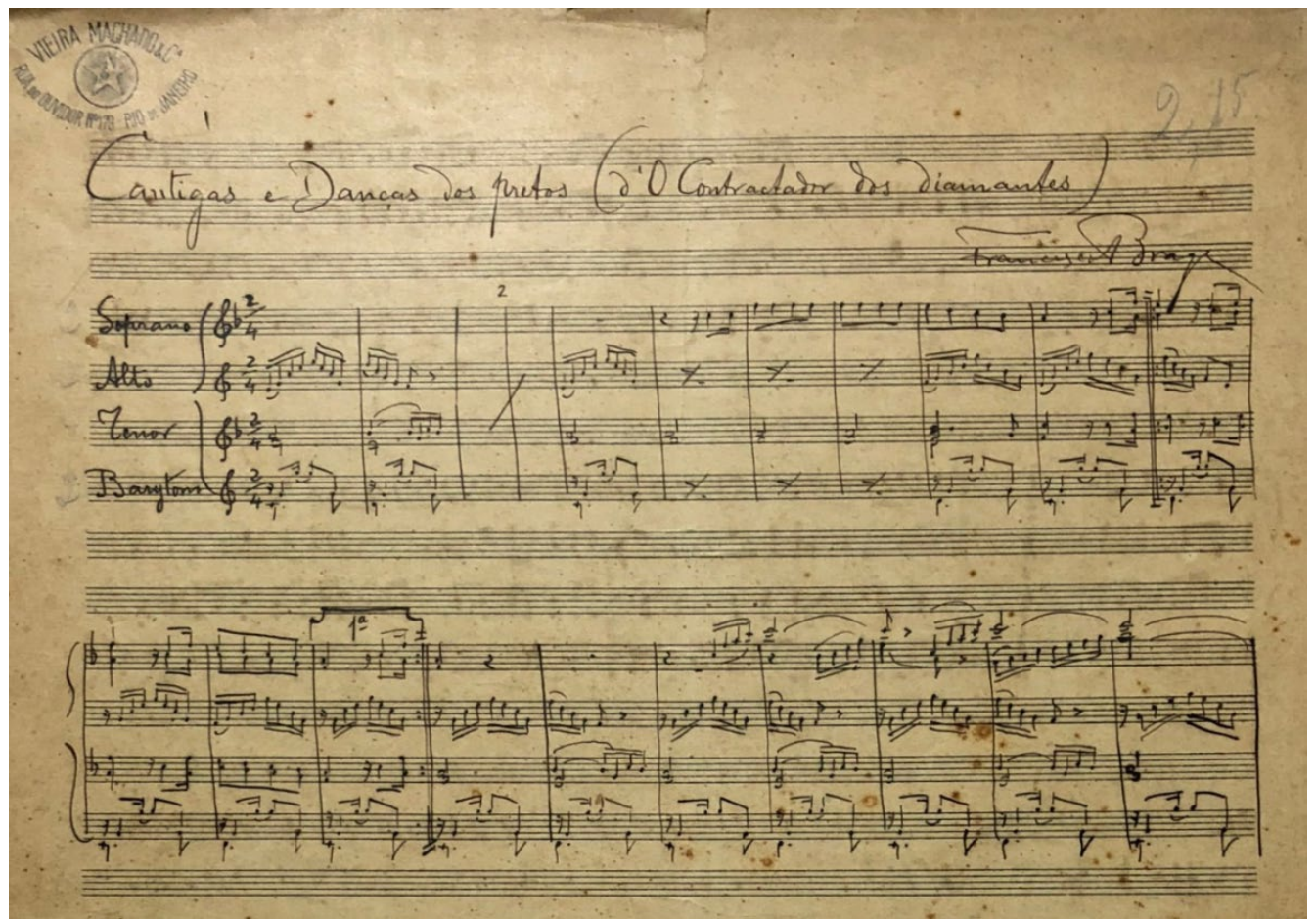

Figura 1 - Cantigas e danças dos pretos, de Francisco Braga (1905). Grade - manuscrito.

Fonte: Manuscrito cedido gentilmente pelo Arquivo da Banda do Corpo de Bombeiros do Rio de Janeiro.
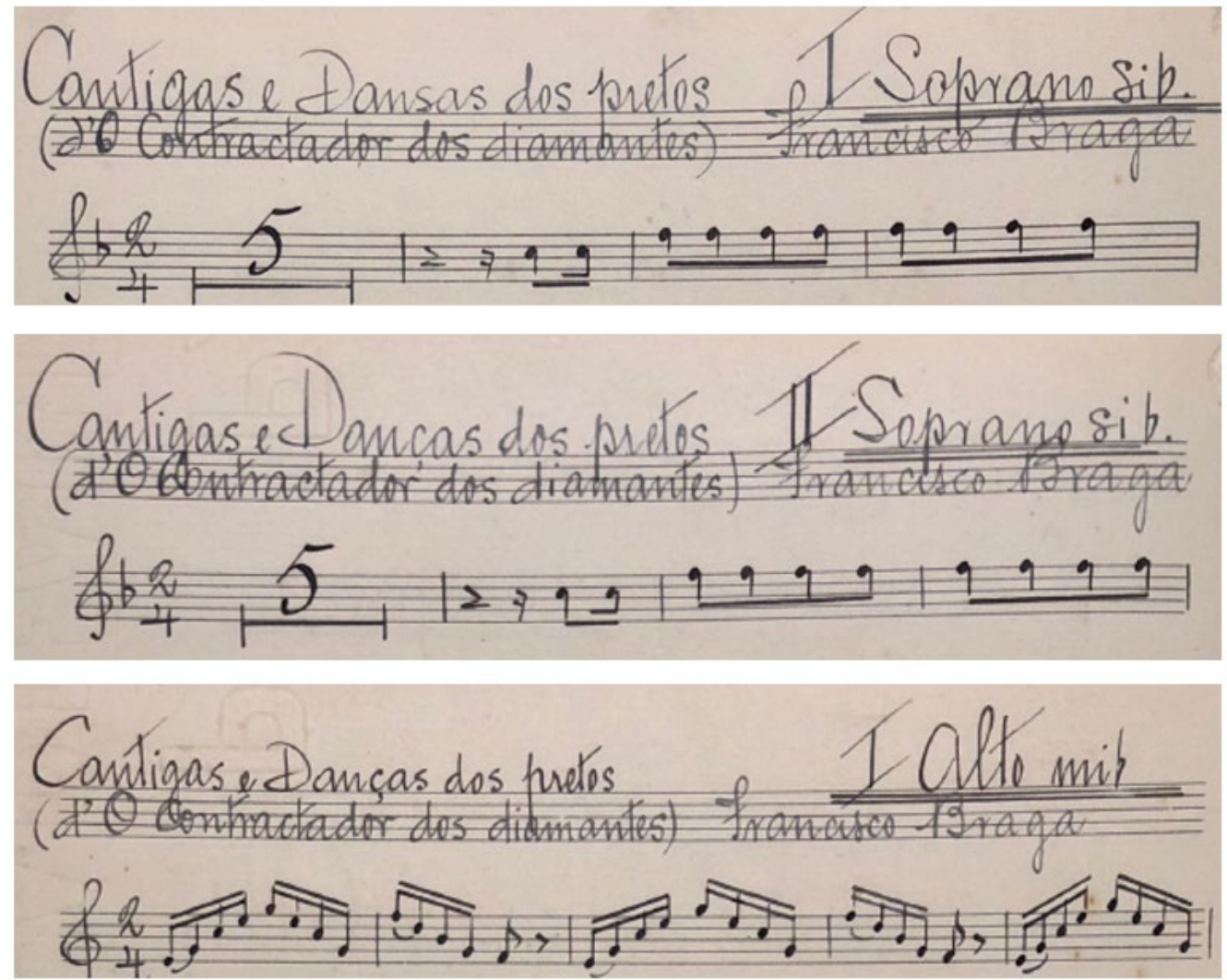

Fig. 2: Manuscrito da obra Cantigas e danças dos pretos, de Francisco Braga (1905). Excertos das partes de saxofone soprano I e II, sax alto I.

Fonte: Manuscrito cedido gentilmente pelo Arquivo da Banda do Corpo de Bombeiros do Rio de Janeiro. 

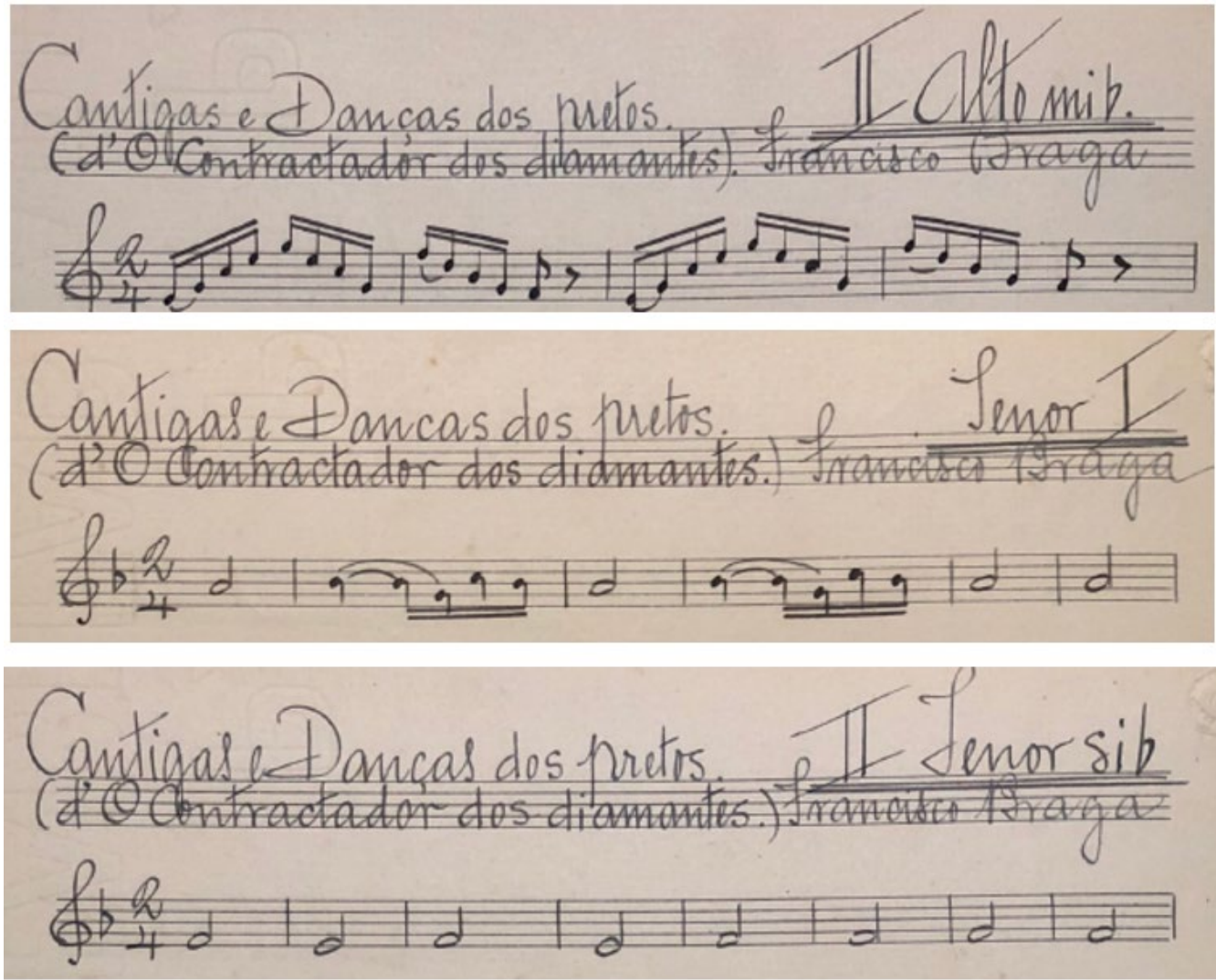

Fig. 3: Manuscrito da obra Cantigas e danças dos pretos, de Francisco Braga (1905). Excertos das partes de saxofone alto II e saxofone tenor I e II.

Fonte: Manuscrito cedido gentilmente pelo Arquivo da Banda do Corpo de Bombeiros do Rio de Janeiro.

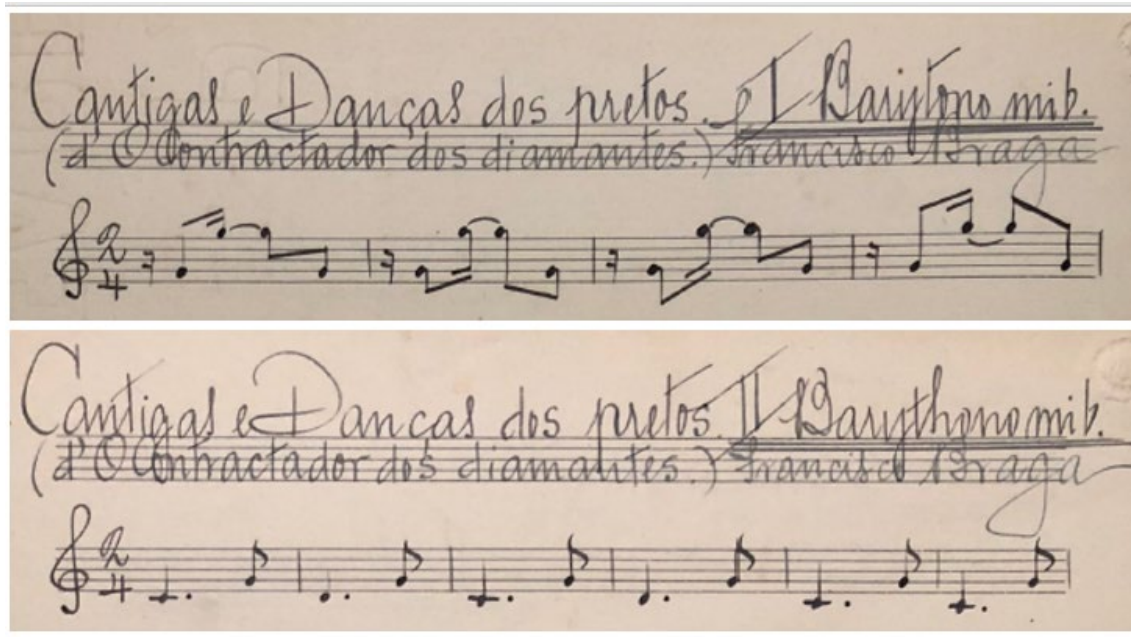

Cantigar Iansas dos pretos. Saxplone Baixo S.

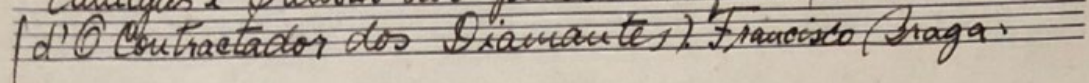

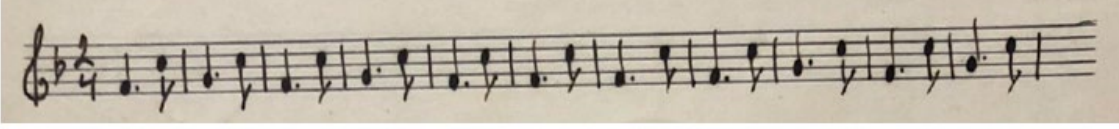

Fig. 4: Manuscrito da obra Cantigas e dança dos pretos, de Francisco Braga (1905). Excertos das partes de saxofone barítono I e II: e saxofone baixo.

Fonte: Manuscrito cedido gentilmente pelo Arquivo da Banda do Corpo de Bombeiros do Rio de Janeiro. 
Em um processo comparativo com manuscritos de outras obras do compositor, elaborado e executado pelo pesquisador Macedo (2019, p. 6-7), é atestada a originalidade da caligrafia de Francisco Braga na maioria das partes do manuscrito de Cantigas e danças dos pretos, havendo divergência apenas na parte de saxofone baixo, conforme demonstrado pela Fig. 4.

Com isso, a disparidade da caligrafia explicitada na comparação entre os manuscritos indica que a parte de sax baixo é uma adição posterior, não pertencendo a Francisco Braga.

Examinando a partitura, percebe-se que a parte do baixo é uma transcrição do barítono II, um substituto, facilitando a execução por situar a música em uma região mais confortável no instrumento maior. Faz sentido pensar que as organizações militares normalmente têm grandes grupamentos e os recursos para a aquisição de instrumentos menos usuais, e, portanto, mais caros, como o saxofone baixo, que nem sempre tem um uso regular na banda de música. Dessa forma, a adaptação da obra de Braga (entre outras) para o instrumento maior justificaria o investimento financeiro.

\section{Identidade nacional a partir de títulos como, Dança dos pretos, Dança de negros e Batuque}

No que diz respeito à música no Brasil, o final do século XIX e início do século XX foi marcado por uma concepção eurocentrista, no entanto, observa-se que a historiografia musical produzida no Brasil sobre o referido período aponta uma certa busca por uma concepção de identidade e emancipação do modelo europeu. Há de se considerar que a influência do negro na cultura brasileira em geral, principalmente na música, foi de fundamental importância. Segundo Lopes (2012), os primeiros indícios da busca por uma identidade nacional ocorrem no meio intelectual brasileiro, causado em parte pelo impacto de teorias europeias a partir de um novo enfoque aos estudos históricos, literários, sociais e antropológicos. Neste contexto, a abolição da escravatura no ano de 1888, torna-se ingrediente significativo no que se refere às discussões sobre as questões de identidade nacional. A efervescência causada pela abolição fortaleceu a classe intelectual e artística no tocante ao reconhecimento da influência da cultura africana no processo de formação cultural brasileira. Como consequência, muitos compositores se apropriaram e empregaram elementos culturais brasileiros, étnicos e populares, transformando-os em materiais musicais. Nessa conjuntura, são concebidas referências para elaboração de material musical folclórico brasileiro a partir dos princípios europeus considerando, sobretudo, a expressão musical urbana por intermédio da dança, da religiosidade, da culinária e da música. Inicialmente, os ritmos que serviram de base para essa concepção de brasilidade ${ }^{3}$ e significação referente aos processos de formação cultural da música brasileira são: a modinha, o lundu, o maxixe, o cateretê, a polca e a habanera.

Quanto à inter-relação de algumas obras musicais examinadas por esta pesquisa com temáticas a partir de títulos como Dança de negros, Dança dos pretos e Batuque,

3 Conjunto de traços considerados distintivos da cultura e condição brasileira, amor e dedicação à pátria brasileira (BRASILIDADE, 2003-2021). 
principalmente obras de compositores da chamada música brasileira de concerto de tradição europeia, percebe-se que boa parte delas se inter-relacionam por intermédio de elementos rítmicos que referenciam sobretudo o maxixe e o lundu. Entre as inúmeras obras que poderiam ser citadas como exemplo da interface entre brasilidade e herança da cultura africana, destacamos algumas obras anteriores a Cantigas e danças dos pretos (1905) que, de alguma forma refletem a busca por uma identidade musical brasileira, e que, talvez, em alguns momentos, também possam ter servido de influência a Francisco Braga em algum momento. Seguindo a ordem cronológica, a primeira é $A$ Cayumba - Dança dos negros (piano), de Carlos Gomes (1856); IV movimento denominado Batuque (Dança de negros) da 1a Suite Brézilienne de Alberto Nepomuceno (1887), Batuque, de Henrique Alves de Mesquita (1894) e Corta Jaca de Chiquinha Gonzaga (1895).

Dentre as obras citadas, embora todas se inter-relacionem por meio dos elementos rítmicos que referenciam o maxixe, a que mais se assemelha a Cantigas e danças dos pretos de Francisco Braga (1905) é Corta Jaca, de Chiquinha Gonzaga (1895). Na esteira deste pensamento, os elementos do maxixe identificados na obra de Francisco Braga, assim como em outras obras do gênero, podem ser observados também em Odeon, de Ernesto Nazareth (1909), conforme se observa na Fig. 5.

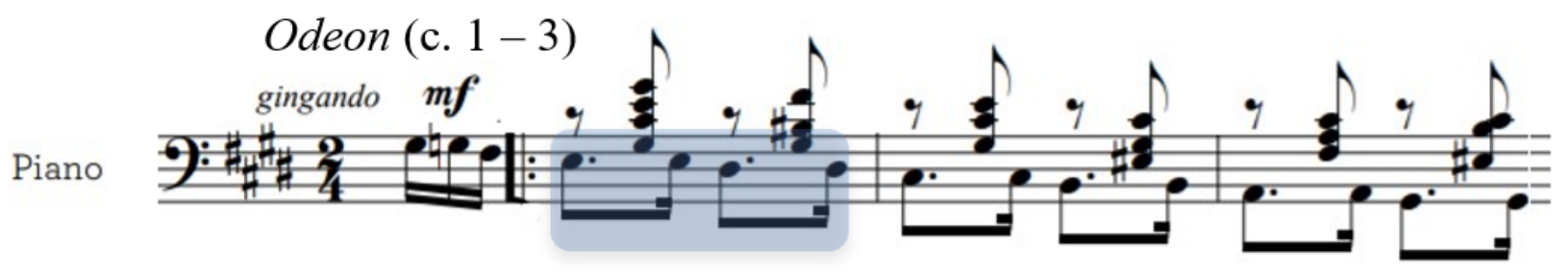

Cantigas e danças dos pretos (c. 37 - 40)

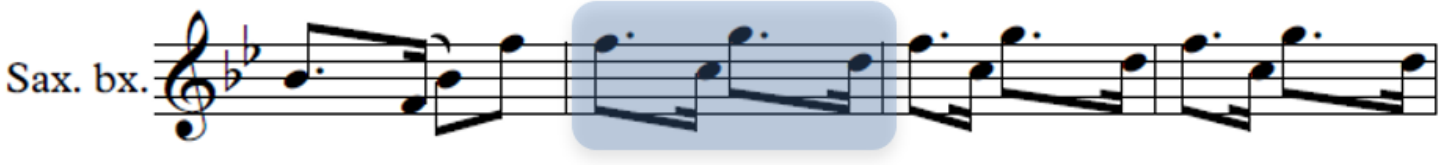

Odeon (c. $37-38)$

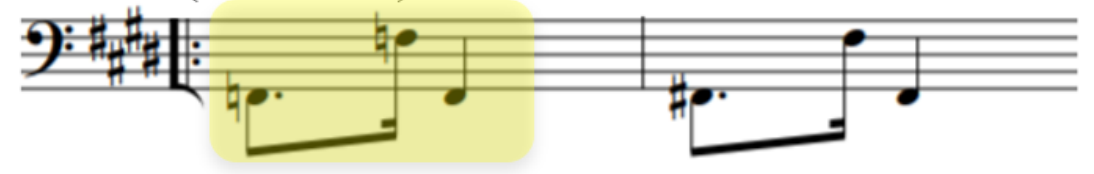

Cantigas e danças dos pretos (c. $70-74)$

Sax. bx.

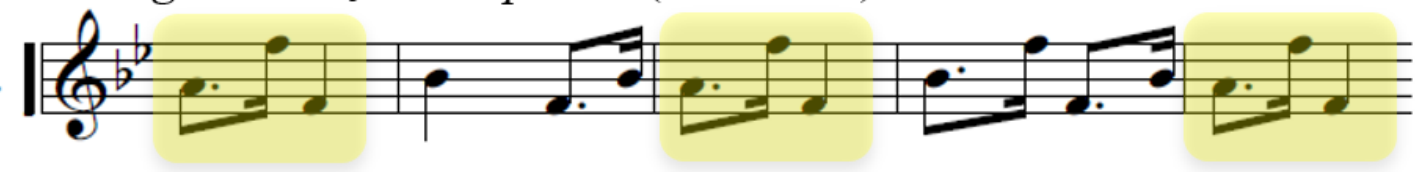

Fig. 5: Variações rítmicas do maxixe em Odeon - Ernesto Nazareth (1909) (piano - mão esquerda), e Cantigas e danças dos pretos, de Francisco Braga (1905), saxofone baixo em Si bemol. Fonte: Odeon (Musica Brasilis; Instituto Moreira Salles. Revisão: Alexandre Dias, 2012). Cantigas e danças dos pretos (Editoração Wesley do Prado Reis, 2019). 
Em relação à Corta Jaca (para piano), embora também possua instrumentação diferente, os elementos comuns vão desde tempo de duração (as duas obras são bem curtas) até fórmula de compasso e estruturas rítmicas análogas. Auditivamente, utilizando como referência as gravações do Ensemble de Saxofones (CANTIGA..., 2021) da Escola de Música do Estado de São Paulo (EMESP) e a gravação de Olinda Allessandrini (piano) (CHIQUINHA..., 2018), ainda que a diferença de andamento distancie um pouco a memória auditiva no efeito comparativo (Cantigas e danças dos pretos - 76 bpm e Corta Jaca - 96 bpm), os elementos rítmicos, tanto estruturais quanto os de condução melódica de Cantigas e danças dos pretos remetem à Corta Jaca. Em uma análise comparativa das partituras é possível visualizar elementos similares, como, por exemplo, terminações com relação de oitava e estrutura rítmica do acompanhamento; figuras rítmicas de movimento em alusão ao batuque e, elementos motívicos/temáticos, como elementos estruturantes de frases, conforme pode ser observado nas Fig. 6-8.
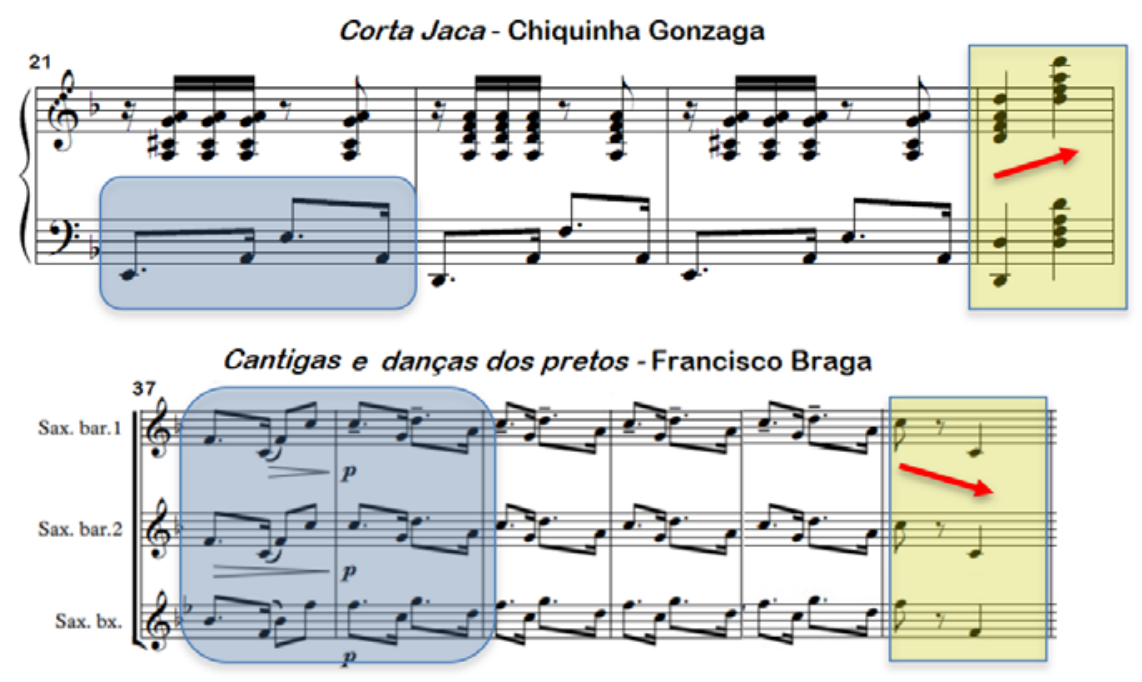

Fig. 6: Elementos análogos no acompanhamento e terminação com relação de 8ª. Fonte: Corta Jaca - Acervo Digital Chiquinha Gonzaga. Editoração: Douglas Passoni; Cantigas e danças dos pretos, Editoração Wesley do Prado Reis (2019).

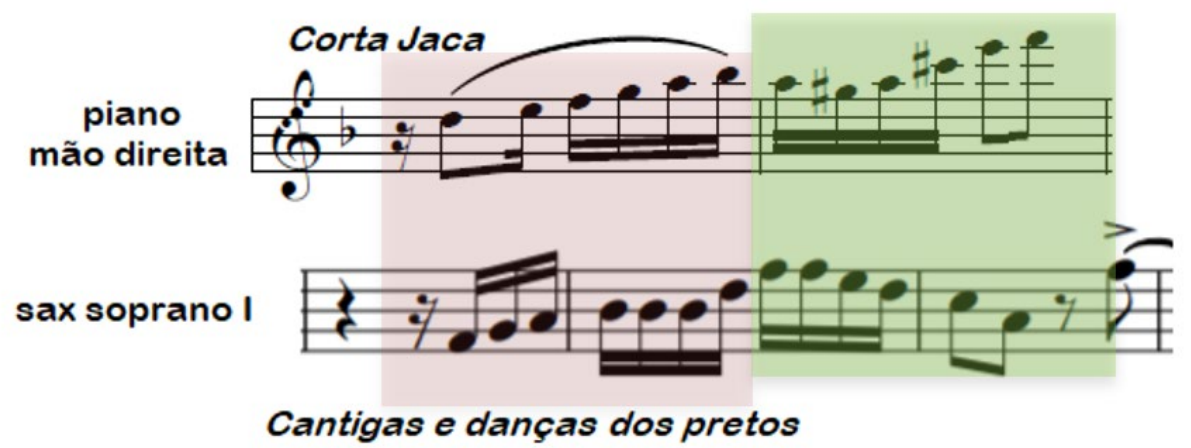

Fig. 7: Estruturas rítmicas análogas. Corta Jaca (c. 5 - 6). Cantigas e danças dos pretos (c. 44 - 46). Fonte: Corta Jaca - Acervo Digital Chiquinha Gonzaga. Editoração: Douglas Passoni; Cantigas e danças dos pretos. Editoração Wesley do Prado Reis (2019). 

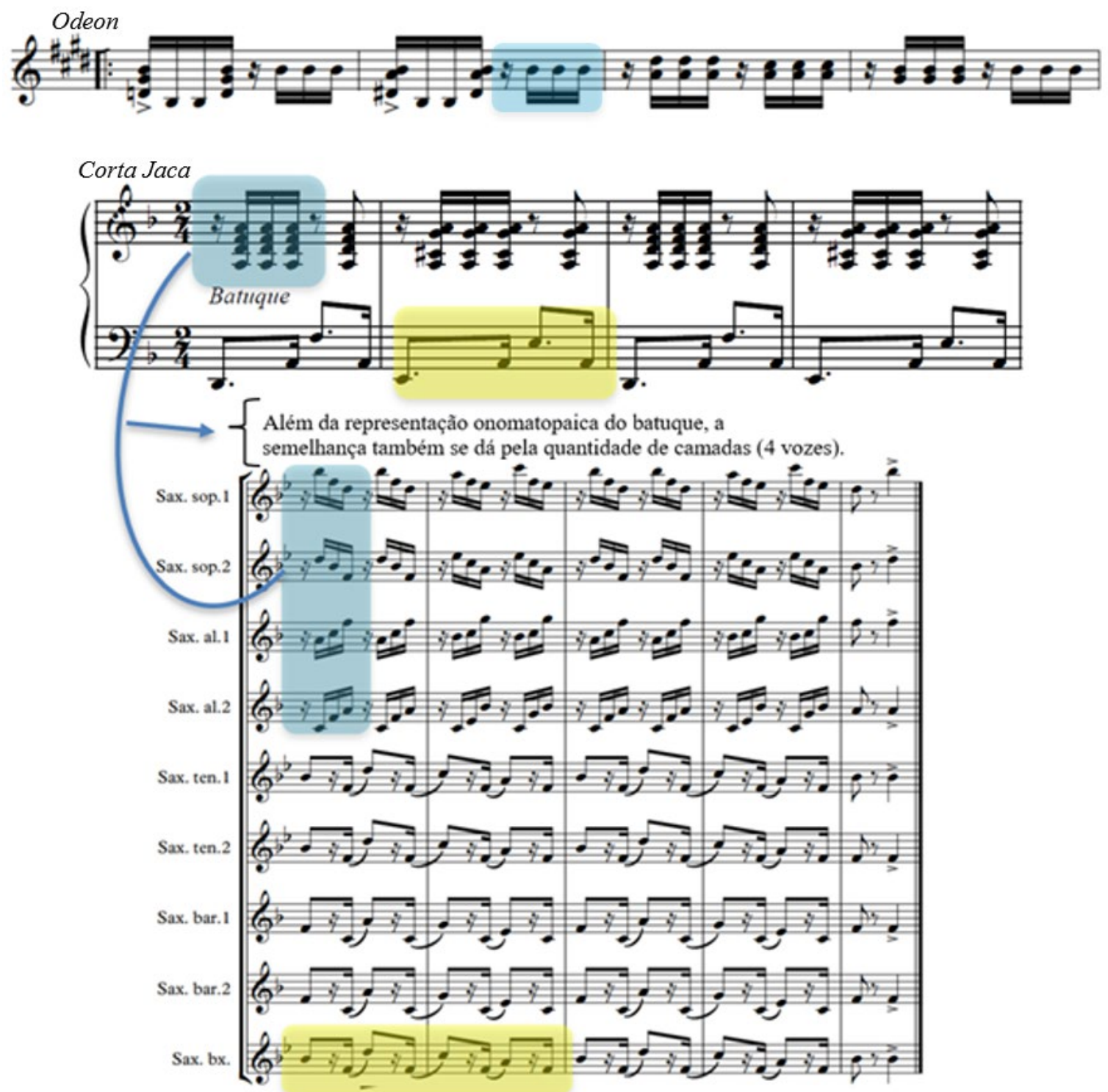

Fig. 8: Elementos rítmicos em alusão ao batuque e similaridade no acompanhamento. Corta Jaca (c. 1 - 5). Cantigas e danças dos pretos (c. 93 - 97) e Odeon (c. 93 - 96). Fonte: Odeon (Musica Brasilis; Instituto Moreira Salles. Revisão: Alexandre Dias, 2012). Corta Jaca (Acervo Digital Chiquinha Gonzaga. Editoração: Douglas Passoni); Cantigas e danças dos pretos (Editoração Wesley do Prado Reis, 2019).

\section{Cantigas e danças dos pretos: características formais e projeção compositiva}

Cantigas e danças dos pretos pertence a uma classe de obras brasileiras que possui como principal característica composicional, o viés nacionalista, sobretudo no que diz respeito às referências africanas como matriz da música brasileira. No que se refere aos elementos de projeção compositiva dessas obras, em estado puro ou fragmentado, em linhas gerais, encontram-se materiais harmônicos e motívicos que remetem à modinha e ao maxixe, além de referências diretas ao batuque em forma de onomatopeia. No 
caso de Cantigas e danças dos pretos, observa-se a proeminência de células rítmicas provenientes do maxixe, principalmente nos instrumentos graves (vozes de acompanhamento), como sax baixo e sax barítono. Entretanto, se considerarmos as três fases do maxixe (CAZES, 2019, p. 98-99) e as variações das células rítmicas ao longo da obra, além das confluências com Corta Jaca (1895) e Odeon (1909), mostradas anteriormente (Fig. 5 -8), Cantigas e danças dos pretos (1905) conserva características significativas do gênero maxixe.

Acerca do material motívico/temático, o compositor utiliza quatro motivos principais que se desenvolvem em forma de variação ao longo da obra. Dos quatro motivos, três são apresentados logo no primeiro compasso, enquanto o quarto, somente no compasso 12, conforme é observado nas Fig. 9-12.
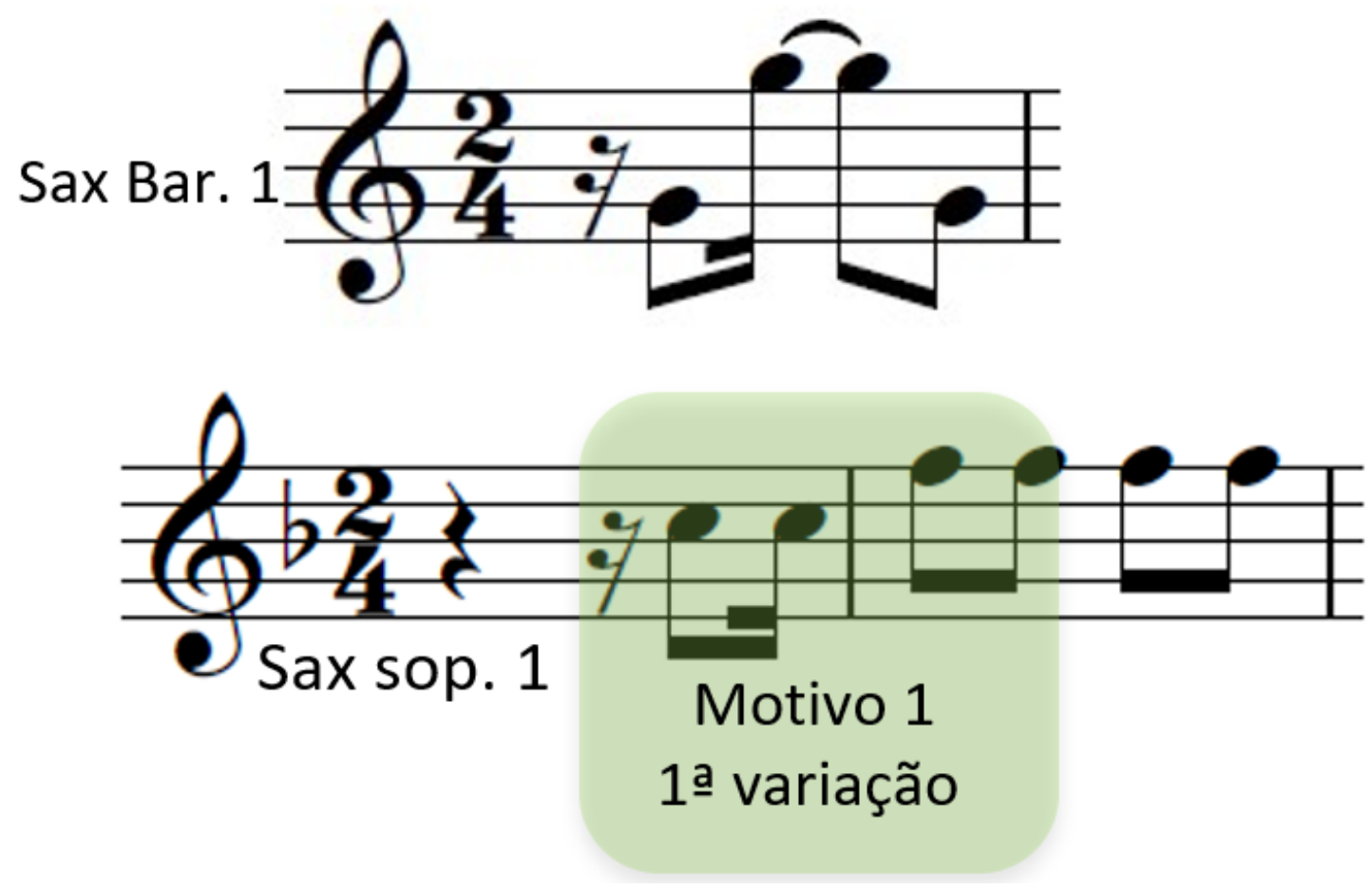

Fig. 9: Motivo 1 - Cantigas e danças dos pretos. Sax barítono. 1 (c. 1) e sax soprano 1 (c. 7 - 8). Fonte: Editoração Wesley do Prado Reis, 2019. 


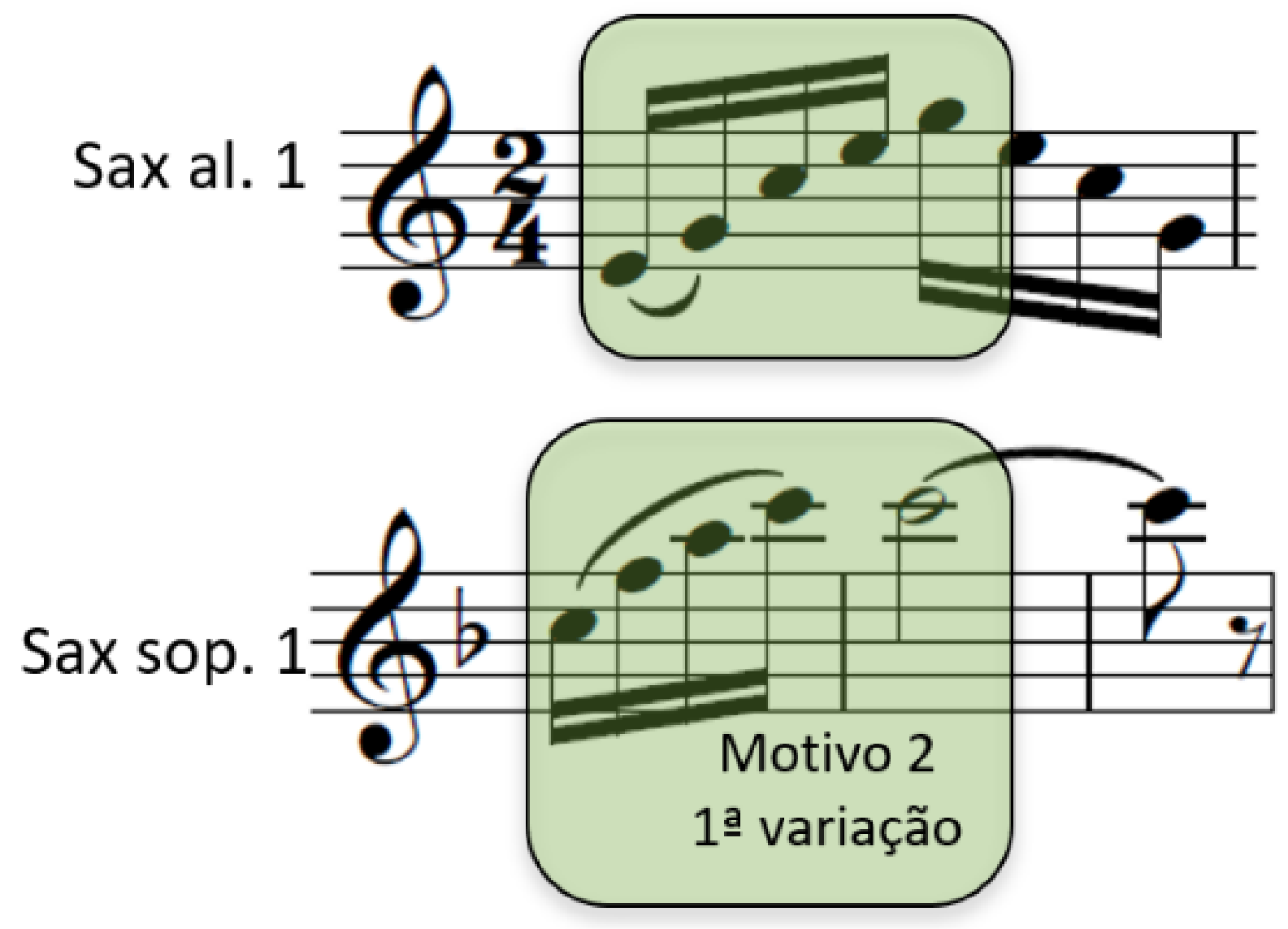

Fig. 10: Motivo 2 - Cantigas e danças dos pretos. Sax alto 1 (c. 1) e sax soprano 1 (c. 17 - 18). Fonte: Editoração Wesley do Prado Reis (2019. 

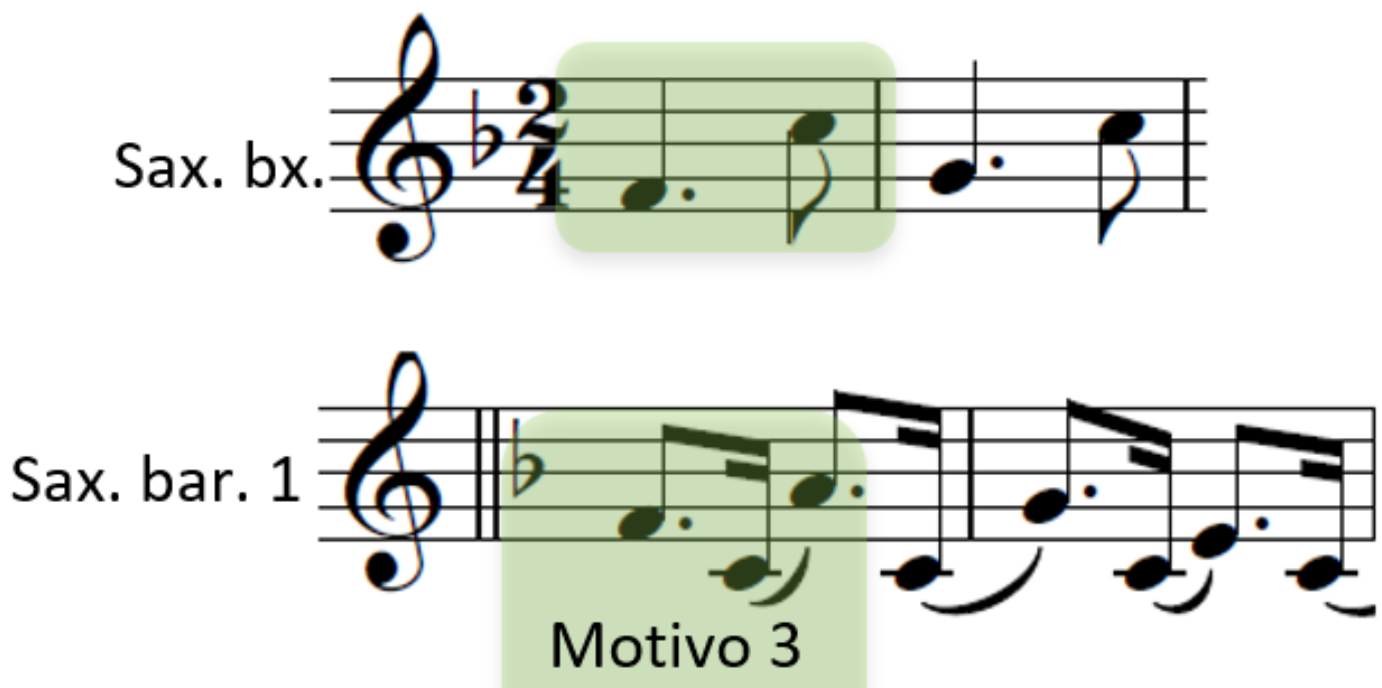

1ํ variação

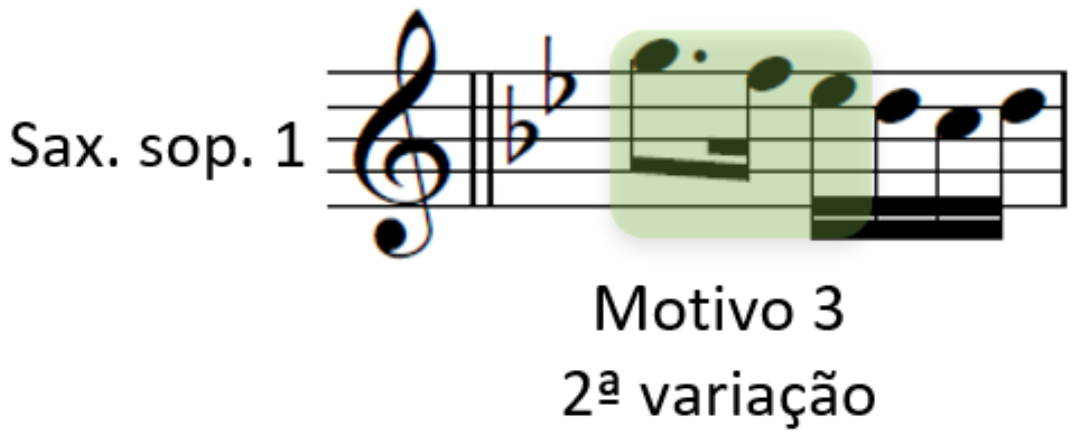

Fig. 11: Motivo 3 - Cantigas e danças dos pretos. Sax baixo 1 (c. 1), sax barítono (c. 23 - 24) e sax soprano 1 (c. 27). Fonte: Editoração Wesley do Prado Reis (2019). 


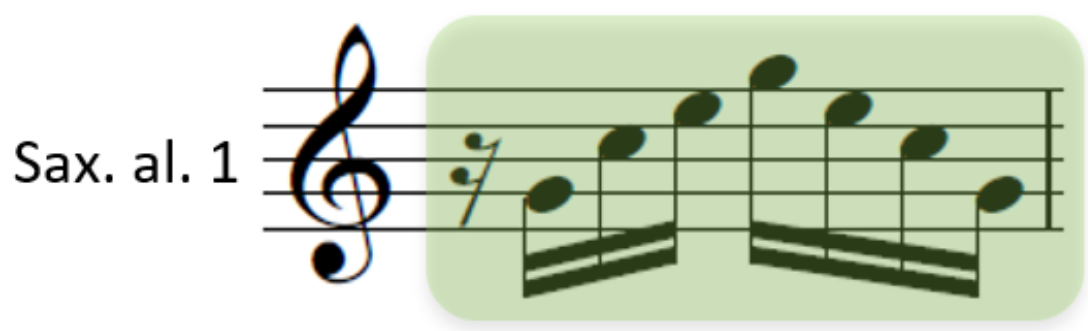

Sax. sop. 1

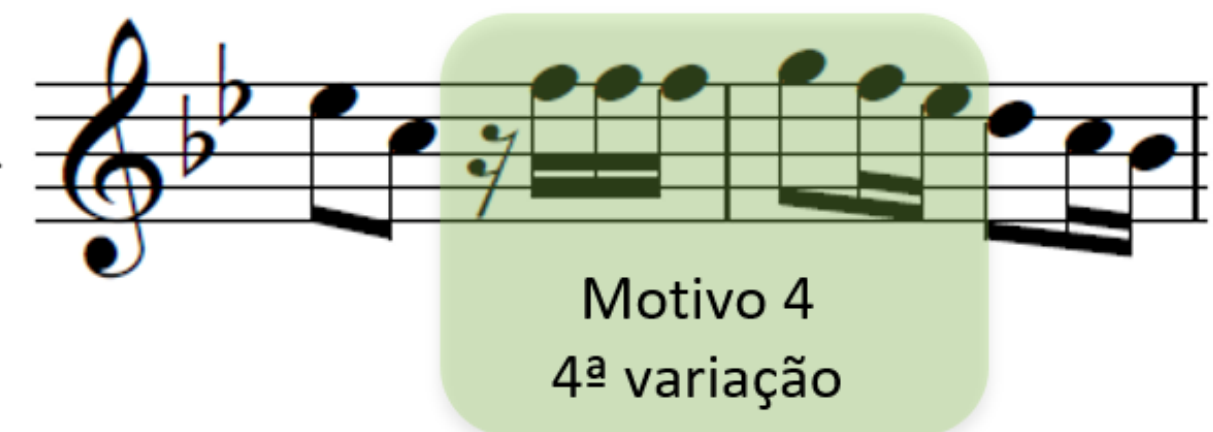

Fig. 12: Motivo 4 - Cantigas e danças dos pretos. Sax alto 1 (c. 12) e sax soprano 1 (c. 32). Fonte: Editoração Wesley do Prado Reis (2019)

Sobre o material harmônico, em uma breve análise sobre os processos composicionais, notabiliza-se uma estrutura harmônica a partir de duas tonalidades: Mi bemol (c. 1-22) e Lá bemol maior (c. 23-97). Em relação às características formais e à projeção compositiva, a obra está organizada da seguinte maneira: Introdução (c. 1-5), Parte A (c. 6-22), Parte B (c. 23-42), Parte B' (c. 43-60), Parte C (c. 61-97). Essa organização pode ser mais bem observada no Quadro 1. 


\begin{tabular}{|c|c|c|}
\hline \multicolumn{3}{|c|}{ Cantigas e danças dos pretos, Francisco Braga (1905) } \\
\hline \multicolumn{2}{|c|}{ FORMA } & Introdução-A - B - B' - C \\
\hline Compasso & Seção & Material Temático \\
\hline $1-5$ & Introdução & $\begin{array}{l}\text { Estruturada na tonalidade de Mi bemol maior, além dos arpejos sobre o } \\
\text { acorde de Mi bemol maior (som real) nas vozes dos saxofones altos } 1 \text { e } \\
\text { 2. A introdução é caracterizada pela apresentação de três dos principais } \\
\text { motivos que compóem o material temático da obra. Motivo } 1 \text { - sax } \\
\text { barítono } 1 \text { (c. 1); Motivo } 2 \text { - sax alto } 1 \text { e } 2 \text { (c. 1); Motivo } 3 \text { - sax baixo } \\
\text { em Si bemol (c. 1). }\end{array}$ \\
\hline $6-22$ & $\mathbf{A}$ & $\begin{array}{l}\text { Ainda sob a tonalidade de } \mathrm{Mi} \text { bemol maior, com predominância dos } \\
\text { acordes de Mi bemol maior, Si bemol maior, Lá bemol maior e Ré } \\
\text { diminuto, ou seja, as funções primárias de tônica, dominante e } \\
\text { subdominante (Ddim }=\mathrm{Bb} 7 \text { sem a fundamental). A Seção é marcada } \\
\text { também pelo desenvolvimento dos motivos } 1 \text { e } 2 \text {, sobretudo nas vozes } \\
\text { dos saxofones soprano } 1 \text { e } 2 \text {, altos e tenores e, apresentação do Motivo } 4 \\
\text { - sax alto } 1 \text { (c. 12). }\end{array}$ \\
\hline $23-42$ & B & $\begin{array}{l}\text { Tonalidade de Lá bemol maior. A partir do uso de estruturas } \\
\text { homorrítmicas e de variações motivicas, em uma espécie de } \\
\text { desenvolvimento do material temático, o trecho é caracterizado pela } \\
\text { ampliação da densidade textural e dos arpejos realizados nas vozes dos } \\
\text { saxofones altos enquanto os saxofones graves (sax tenor, barítono e } \\
\text { baixo) mantêm células rítmicas do maxixe em uma espécie de ostinato. }\end{array}$ \\
\hline $43-60$ & $\mathbf{B}^{\prime}$ & $\begin{array}{l}\text { Reprise do material temático com ocorrência de algumas } \\
\text { modificaçôes: retirada de } 2 \text { compassos e outras alterações relacionadas } \\
\text { ao material temático, como, por exemplo, compasso } 43 \text {, início da Seção } \\
\text { B'. }\end{array}$ \\
\hline $61-97$ & $\mathbf{C}$ & $\begin{array}{l}\text { Seção permanece em Lá bemol maior, porém com redistribuição do } \\
\text { material temático em forma de variação. No entanto, apesar de } \\
\text { permanecer em Lá bemol maior e retomar alguns temas, Francisco Braga } \\
\text { consegue manter o interesse do ouvinte remanejando o material } \\
\text { harmônico, como, por exemplo, criando uma textura mais rarefeita nas } \\
\text { vozes graves entre os compassos } 77 \text { e } 79 \text {. Nos compassos finais (c. } 93 \text { - } \\
96 \text { ), enquanto as vozes graves empregam um ritmo maxixado, os } \\
\text { instrumentos agudos (sopranos e altos) aludem ao batuque por meio de } \\
\text { células rítmicas características do gênero. A peça termina com uma típica } \\
\text { cadência V - I, Mi bemol maior com sétima menor resolvendo na tônica } \\
\text { da tonalidade de Lá bemol maior. }\end{array}$ \\
\hline
\end{tabular}

Quadro 1: Cantigas e danças dos pretos, de Francisco Braga (1905). Estrutura composicional. Fonte: Elaboração própria.

\section{Aspectos interpretativos}

Com relação aos aspectos técnicos interpretativos, utilizaremos como referência o único registro da obra a partir de uma formação que mais se aproxima da original, a gravação do Ensemble de Saxofones da EMESP ${ }^{4}$ realizada pelos alunos da classe do professor e saxofonista Milton Vito, em novembro de 2019, podendo ter sido esta, talvez, a primeira audição da obra na cidade de São Paulo (CANTIGA..., 2021). Nessa ocasião, o grupo contou com a participação de 2 saxofones soprano, 3 altos, 2 tenores e 2 barí-

4 EMESP Tom Jobim: Escola de Música do Estado de São Paulo - instituição do Governo do Estado de São Paulo e da Secretaria de Cultura e Economia Criativa do Estado, gerida pela organização social Santa Marcelina Cultura. Fundada em outubro de 1989, a instituição foi chamada inicialmente de Universidade Livre de Música (ULM) e teve Tom Jobim como primeiro reitor e presidente do conselho. 
tonos. Buscando uma interpretação próxima de sua concepção original, a metodologia aplicada para preparação de Cantigas e danças dos pretos ocorreu em duas etapas. Segundo Vito ${ }^{5}$ (2021), a primeira etapa se resumiu na providência de uma nova edição da partitura a fim de possibilitar uma melhor leitura, visto que a qualidade dos originais não oferecia condições favoráveis. Para essa apresentação, foram realizados dois ensaios (2 ${ }^{a}$ etapa). Em relação à interpretação e à performance, o grupo encontrou alguns empecilhos relacionados à acústica do local da apresentação, segundo Vito (VITO, 2021):

[Milton Vito sobre a execução da obra]. [...] Para os alunos, foi de fácil compreensão. Daquilo que estava escrito, tivemos que colocar algumas articulações, não tinha nada relacionado nesse sentido. Como no barroco ou no jazz, a música é escrita de uma forma e se toca diferente, em Cantigas e danças dos pretos tem um certo swing (isso não consta na partitura). Na EMESP, ela ficou um pouquinho mais lenta. Se tocássemos mais rápido, por causa do ambiente, do local, não funcionaria. Mesmo assim, se olharem os meus gestos eu estou pedindo para tocarem um pouco mais pra frente, mas, a reverberação não permite, por mais que queira tocar um pouco mais rápido, por causa do ambiente, a música leva para trás. Eles (alunos) precisam ouvir o que está acontecendo ritmicamente. Quando é um lugar seco é mais fácil, um lugar que tem eco, por exemplo, assim como no saguão da EMESP, é mais complicado por conta da questão acústica. Então, eu creio que ela é um pouquinho mais pra frente, talvez uns 8 bpm, talvez, no máximo 12 bpm (VITO, 2021).

\section{Diálogo Sonoro ao Luar, seresta para saxofone alto e bombardino em Dó, de Francisco Braga (1945?): incongruências e interfaces estilís- ticas}

Publicada no VI Boletim Latino-Americano de Música, em 1946, Diálogo Sonoro ao Luar - para saxofone alto e bombardino - configura-se como a segunda participação do saxofone no repertório de câmara de Francisco Braga.

Entre as particularidades que permeiam o entorno de Diálogo Sonoro ao Luar estão algumas incongruências, a incógnita sobre qual seria de fato a data de composição da obra e a hipótese de ter sido a última composição de Francisco Braga, visto que o compositor faleceu em 1945. O único registro da partitura de que se tem notícia é o da publicação no VI Boletim Latino-Americano de Música de 1946. No entanto, a partir da pesquisa de Volpe (1994), não se descarta a possibilidade de a obra ser anterior a 1930 ao observar que Diálogo Sonoro ao Luar encontra-se catalogada junto a outras obras brasileiras de câmara compostas no período entre 1850 e 1930. A pesquisa de Volpe utiliza, além do critério data da composição entre os anos de 1850 e 1930, compositores nascidos entre 1834 e 1884 (VOLPE, 1994, p. 134 e 144). 
Outra questão que se coloca está relacionada à indagação de qual ou quais seriam as motivações de Francisco Braga que o levaram a escrever para uma formação tão peculiar. Quanto aos aspectos construtivos, segundo os pesquisadores Adler (2002) e Henrique (1988), tanto o saxofone, patenteado em 1846, quanto o bombardino (eufônio), patenteado em 1845, pertencem aos instrumentos desenvolvidos pelo construtor de instrumentos Adolphe Sax (1814-1894). Partindo do princípio de que ambos os instrumentos são "irmãos", não se pode descartar a hipótese de que tenha sido justamente essa peculiaridade a força inspiradora para que Francisco Braga compusesse Diálogo Sonoro ao Luar.

Quanto à notabilidade da obra dentro do repertório dos instrumentos, tanto o saxofone quanto o eufônio, é difícil mensurar para qual dos instrumentos (eufônio ou saxofone) Diálogo Sonoro ao Luar é mais representativo. No entanto, considerando que ambos os instrumentos são novos se comparados aos instrumentos tradicionais de sopro já consagrados no repertório orquestral, pode-se afirmar que a peça possui grau de importância bastante similar para ambos.

\section{A Seresta}

Em meio à vasta produção musical de Francisco Braga, a seresta para saxofone alto e bombardino em Dó intitulada Diálogo Sonoro ao Luar chama atenção também pelo ponto de vista composicional, sobretudo no que diz respeito ao nacionalismo. $O$ compositor e musicólogo Bruno Kiefer (1976, p. 134) deixa claro ao destacar o caráter "seresteiro tipicamente nosso", elegendo Diálogo Sonoro ao Luar como uma das obras de Francisco Braga, símbolo da brasilidade nacionalista.

Apesar de o gênero seresta pertencer ao universo da chamada música popular brasileira urbana no Brasil, a estilização do gênero foi muito utilizada pelos compositores da música de concerto, sobretudo na primeira metade do século XX. Entre os muitos exemplos, podemos citar a Seresta n.1 para quarteto de cordas de Radamés Gnattali (1930), as Serestas de Villa-Lobos, ciclo de 14 canções reunidas em uma coleção, compostas entre 1925 e 1926 (da primeira à décima) e as últimas duas, entre 1943 e 44, além da Seresta para pequena orquestra, de Francisco Mignone (1976).

O vocábulo seresteiro, de acordo com o dicionário Michaelis, denota aquele que canta músicas típicas de seresta ou serenata. Também denominado serenateiro, serenatista e sereneiro. O termo seresta na língua portuguesa é designado como um conjunto de composições de características popular e urbana. De acordo com Picchi (2010, p. 30), a seresta tem origem na serenata, um gênero europeu, surgido a partir do Romantismo como uma peça característica e independente. Já no dicionário Grove, é mencionada apenas a palavra serenata, definida como uma saudação musical, geralmente realizada fora das portas, à noite, para uma pessoa amada ou uma pessoa de valor (UNVERRICHT; EISEN, 2001). Em uma recente pesquisa realizada por Souza (2010), foi observada uma

6 Original: "Serenade: The term originally signified a musical greeting, usually performed out of doors in the evening, to a beloved or a person of rank". 
modificação na aplicação do termo em algumas regiões, como, por exemplo, nas cidades de Conservatória $(R J)$ e Niterói $(R J)$, onde a palavra seresta é utilizada para lugares fechados e serenata para execuções ao ar livre (SOUZA, 2010, p. 17). Entretanto, apesar de algumas incongruências terminológicas, há uma certa convergência no que se refere à seresta. Sobre a atualização trazida por Souza (2010), é importante considerar que um gênero musical se expande e se transforma com o passar do tempo, podendo assumir características variadas sem perder a essência, como por exemplo, o jazz. No caso da obra Diálogo Sonoro ao Luar - seresta para saxofone alto e bombardino em Dó, o que talvez Francisco Braga quisesse de fato, era contribuir para a construção de um vocabulário mais brasileiro de característica popular urbana, algo muito atual e almejado por muitos compositores brasileiros de sua época.

Sob essa perspectiva, a utilização de um gênero musical por um determinado compositor constitui-se em um aspecto importante para o entendimento de seus ideais estéticos. Segundo Volpe (1994), os títulos das obras camerísticas compostas no início do século XX no Brasil demonstram certa preocupação em forjar um vocabulário mais brasileiro, senão nacionalizante, como se observa nos seguintes títulos: Nostalgia, Serenata Brasileira, de Elpídio Pereira; Serenata rústica, de Bento de Albuquerque Moçurunga; Diálogo Sonoro ao Luar - Seresta, Impressões da roça, Sol poente, Toada, Minha terra, Visões, Cantilena nupcial e Bendengo, de Francisco Braga (VOLPE, 1994, p. 144). Sobre o repertório camerístico brasileiro na virada do século XIX e primeira metade do século XX, um levantamento elaborado por Volpe (1994) aponta uma grande produção musical neste sentido e, os compositores que mais escreveram para formações camerísticas foram Glauco Velasquez, com 44 títulos e, Francisco Braga, com 31 títulos (VOLPE, 1994, p. 141). Na esteira da produção musical brasileira para formação camerística deste período, Volpe também destaca que, entre 1890 e 1920, além da edição de muitas obras brasileiras em países europeus, a maioria das editoras cariocas publicou essa música de câmara oriunda de gêneros populares estilizados. No que se refere ao nível técnico desse repertório que circulava comercialmente, a maioria trata de peças de pequena extensão e dificuldade técnica mediana, acessível a um instrumentista amador ou estudante, principal consumidor dessas partituras. Em corroboração e fortalecimento a essa informação, ao analisarmos as dificuldades técnicas interpretativas de Diálogo Sonoro ao Luar, exceto pelo caráter seresteiro e sincopado, desde o conforto disponibilizado pela armadura de clave com 2 bemóis (som real) e a região da tessitura onde cada um dos instrumentos toca (saxofone alto e bombardino em Dó), constata-se que a obra não oferece grandes desafios aos intérpretes.

No tocante ao nível técnico exigido aos intérpretes nas obras desse período, comparando o número de obras originais e transcrições, apesar de uma quantidade significativa de obras originais, a maioria trata de obras arranjadas para um conjunto instrumental reduzido, geralmente duos e algumas com versões para piano solo (VOLPE, 1994, p. 149). 


\section{Diálogo Sonoro ao Luar: material harmônico, motívico e temático}

Referente à manipulação do material motívico e temático, identifica-se que Francisco Braga trabalha com três motivos principais. O primeiro - motivo 1 (c. 1) de caráter mais melódico, e aspecto dual, em uma espécie de junção entre diatonismo e cromatismo, estrutura-se sobre uma escala pentatônica sobre o modo Eólio na voz do bombardino, acrescido de uma aproximação cromática (Dó \#), somado a dois intervalos no final do compasso 1 (3a menor) e início do compasso 2 (4a $\mathrm{J}$ ). Na sequência, o motivo 1 é reapresentado na íntegra de forma transposta uma oitava acima, na voz do saxofone alto em Mi bemol. O segundo - motivo 2, possui um aspecto mais rítmico de característica sincopada, e, a primeira apresentação acontece no compasso 3, também na voz do bombardino, conforme se observa na Fig. 13.

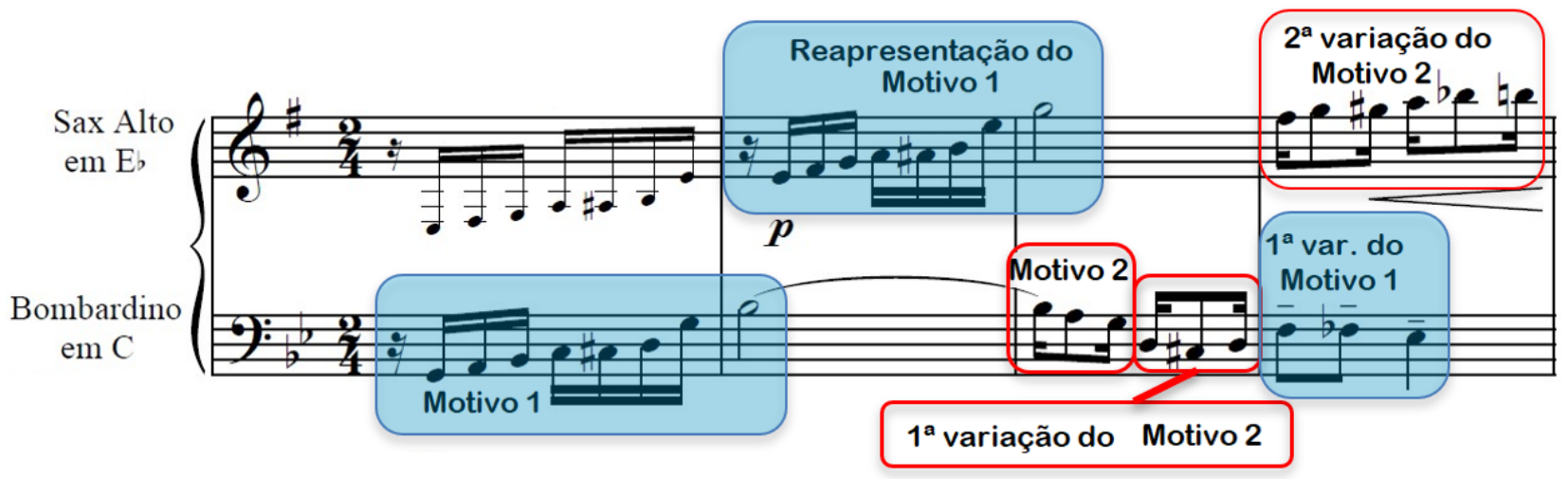

Fig. 13: Motivo 1 e 2 - primeiras variações. Diálogo Sonoro ao Luar, Francisco Braga (s.d.), (c. 1 - 4). Fonte: (1946).

Após as primeiras apresentações dos motivos 1 e 2, a partir do compasso 4, já em forma de variação, tanto o motivo 1 quanto o motivo 2 passam a ser utilizados na maioria das vezes em sobreposição de um ao outro, em uma espécie de contraponto. Por exemplo, quando a primeira voz (saxofone) desenvolve um tema a partir do motivo 1 , seja no estado puro ou em forma de variação, a segunda voz (bombardino) em contraponto, desenvolve outro tema de caráter mais rítmico em forma de acompanhamento a partir do motivo 2, e vice-versa ao longo de toda a obra. Quanto ao motivo 3, apesar de aparecer somente no compasso 10 na voz do bombardino, não é menos importante que os dois anteriores, é justamente a partir desse motivo que o compositor emprega o caráter rítmico da peça, bastante utilizado em suas canções de câmara, assemelhando-se à célula predominante do maxixe ou da habanera, utilizando-o em forma de acompanhamento de forma alternada, ora na voz do bombardino, ora na voz do saxofone (Fig. 14). 


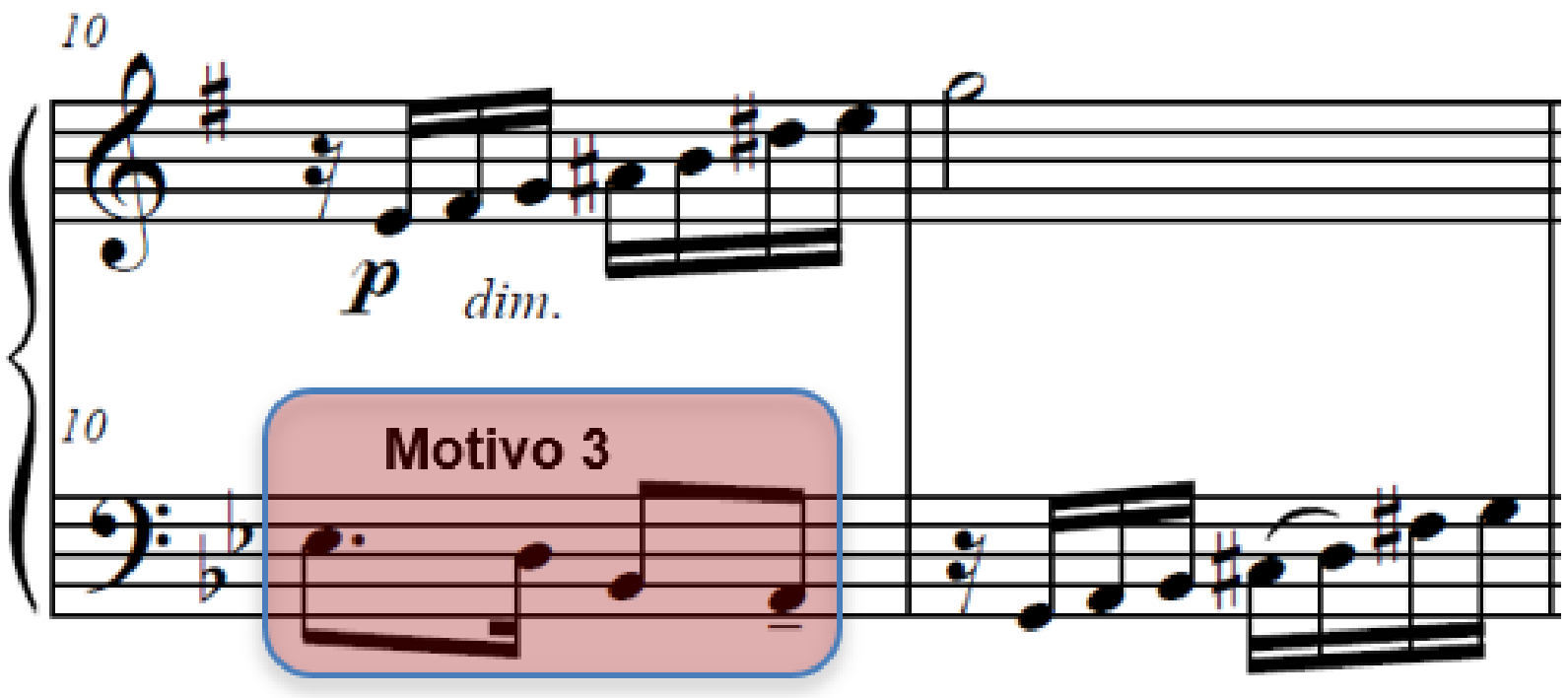

Fig. 14: Primeira apresentação do Motivo 3. Diálogo Sonoro ao Luar (c. 10 - 11). Fonte: (1946).

No que se refere à manipulação do material harmônico, destaca-se a meticulosidade de Francisco Braga, logo na abertura da obra, ao utilizar uma aproximação cromática ${ }^{7}$, elemento composicional utilizado na música popular tanto para acordes como para notas. Sobre esses aspectos, observa-se que a abertura da peça ocorre por intermédio de uma escala pentatônica ascendente sobre o modo Eólio. A partir disso, percebe-se que a aproximação cromática por meio da nota Dó\#, possui como objetivo a nota Ré natural (nota de chegada), cuja representação neste contexto é de dominante de Sol menor, tonalidade predominante da obra (Fig. 15).

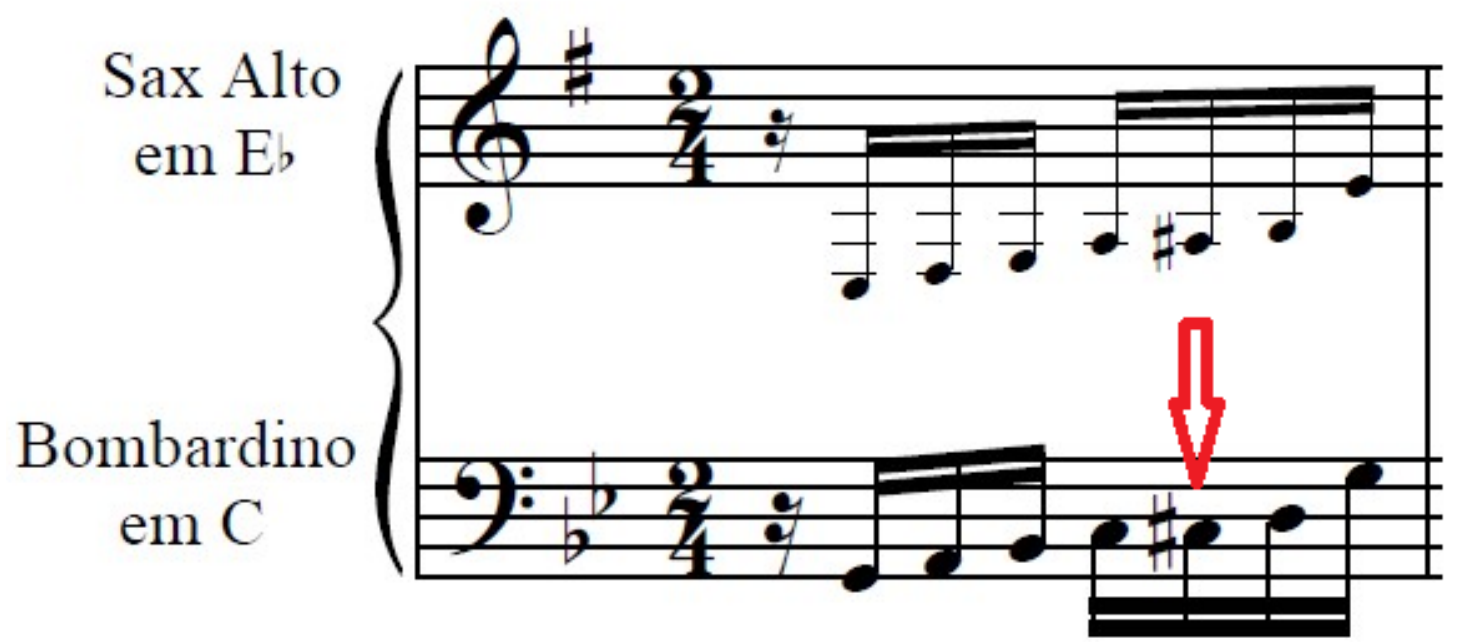

Fig. 15: Aproximação cromática. Escala pentatônica sobre o modo Eólio. Diálogo Sonoro ao Luar, seresta para saxofone alto e bombardino em Dó, Francisco Braga (s.d.), compasso 1. Fonte: (1946).

7 Aproximação cromática são notas ou acordes que possuem a função da aproximação por intermédio de intervalo cromático. Geralmente têm curta duração e pode ser compreendida também como notas ou acordes de passagem dependendo do contexto. 
Ainda sobre o engendramento de Francisco Braga no sentido de busca por unidade da obra, além da característica sincopada apresentada pela primeira vez no compasso 3, o compositor elege um aspecto dual no que se refere ao material motívico e temático ao escolher o diatonismo e o cromatismo como plataforma estrutural. Dessa maneira, o compositor desenvolve ao longo da obra uma relação contrapontística, sobrepondo estruturas diatônicas sobre elementos cromáticos ou vice-versa, intercalando entre as duas vozes ou, na mesma voz.

Referente a uma busca por elementos que deem sentido de unidade estrutural, parece-nos que Francisco Braga estabelece essa relação ao utilizar o mesmo material motívico e temático tanto no início como no final da peça. No início, notabiliza-se o diatonismo por meio da utilização da escala pentatônica sobre o modo Eólio (Sol menor), acrescido do uso da aproximação cromática por intermédio da nota Dó\#, na voz do bombardino (c. 1) e, logo à frente, a aplicação do cromatismo em uma escala ascendente iniciando com a nota Fá\# na voz do saxofone (c. 4, som escrito) estabelecendo como nota de chegada ou meta harmônica, a nota Dó (c. 5 - som escrito, Fig. 16).

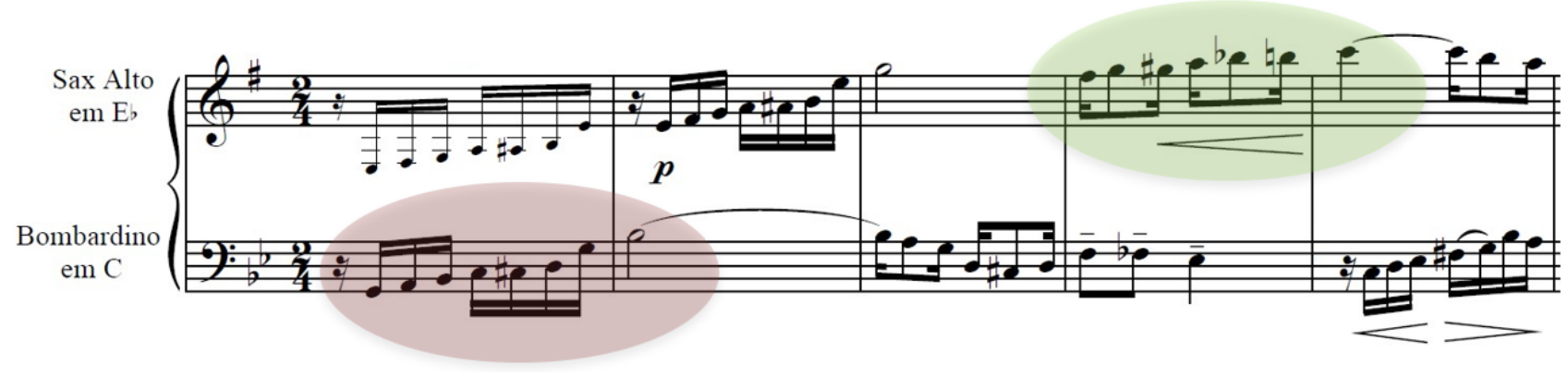

Fig. 16: Elementos de unidade estrutural: escala pentatônica de Sol menor + aproximação cromática (c. 1), bombardino. Escala cromática (c. 4), saxofone. Fonte: (1946).

Nos dois últimos compassos (c. 92-93), de forma bastante interessante, percebe- se uma tentativa de reforçar a tonalidade de Sol menor, visto que em alguns momentos da peça ocorre uma dubiedade em relação ao centro harmônico. Francisco Braga sintetiza a ideia dualista apresentada no início e que permeou toda a obra colocando a mesma nota de abertura (nota Sol) como meta harmônica (nota de chegada) a partir da utilização de duas escalas simultaneamente: uma escala cromática ascendente na voz do saxofone e a escala de Sol menor harmônica descendente na voz do bombardino, conforme se observa na Fig. 17. 


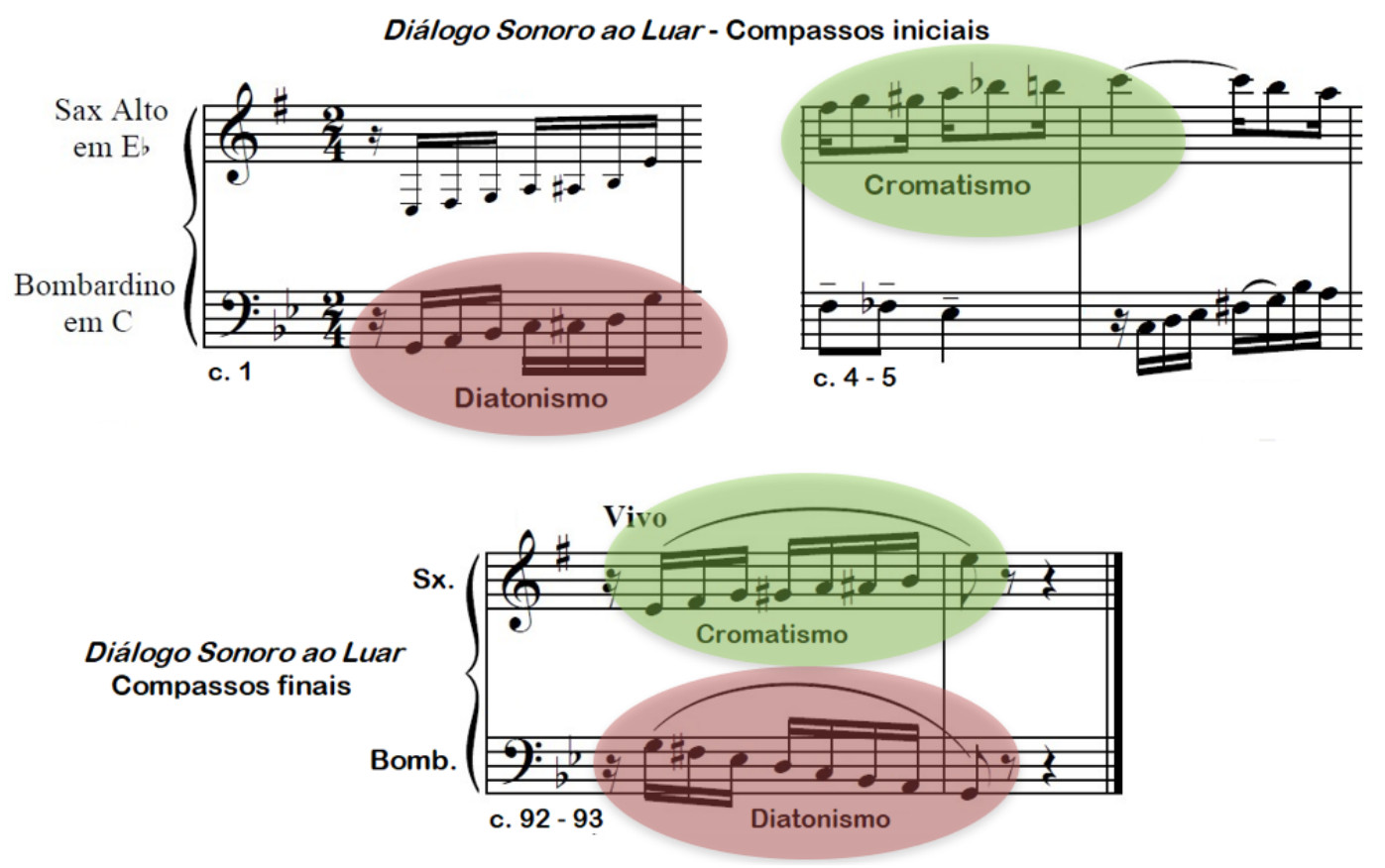

Fig. 17: Elementos de unidade estrutural. A ideia dualística de cromatismo e diatonismo de forma estrutural no início, empregada novamente no encerramento da obra. Fonte: (1946).

Conforme visto na Fig. 17, é possível observar uma espécie de resumo do material harmônico utilizado. Francisco Braga manipula o material fazendo com que a nota final seja a fundamental da tonalidade de Sol menor em ambas as vozes (saxofone e bombardino), como também em referência ao dualismo que permeou toda a obra (diatonismo e cromatismo), terminando com um movimento vivo em duas escalas caminhando em direções opostas, mas objetivando o mesmo ponto de chegada, a nota Sol.

\section{Análise da forma}

No tocante à forma de Diálogo Sonoro ao Luar, ela se estrutura em quatro partes: Seção A (c. 1-19), Seção B (c. 20-48), Transição (c. 49-54), Seção A' (c. 55-72) e Seção C (c. 73-93), conforme pode ser observado no Quadro 2. 
Diálogo Sonoro ao Luar - seresta para bombardino em C e saxofone alto, Francisco Braga (s.d.)

\begin{tabular}{|c|c|c|}
\hline \multicolumn{2}{|c|}{ FORMA } & $\mathbf{A}-\mathbf{B}-$ Transição $-\mathbf{A}^{\prime}-\mathbf{C}$ \\
\hline Compasso & Seção & Material Temático \\
\hline $1-19$ & $\mathbf{A}$ & $\begin{array}{l}\text { Seção estruturada em uma escala pentatônica sobre o modo Eólio. Apesar } \\
\text { da Seção A terminar em Si bemol maior (c. 19), o centro sonoro transita } \\
\text { de forma bastante contundente entre duas regiôes harmônicas (Si bemol } \\
\text { maior e Sol menor) com predominância de Sol menor. O principal } \\
\text { material motívico e temático utilizado deriva-se dos três motivos } \\
\text { principais: Motivo 1- Rítmico, intervalar e melódico (c. 1); Motivo 2- } \\
\text { Rítmico / Sincopado (c. 3) e Motivo 3- Rítmico / Bordão de } \\
\text { acompanhamento / Figuras rítmicas do maxixe. No que diz respeito ao } \\
\text { material harmônico, notabiliza-se a predominância do uso de } \\
\text { sobreposição entre cromatismo e diatonismo. }\end{array}$ \\
\hline $20-48$ & B & $\begin{array}{l}\text { Seção caracterizada pela modulação indicada na mudança de armadura } \\
\text { de clave para Mi bemol maior. O trecho também é marcado pelo emprego } \\
\text { de aspectos melódicos mais lineares. Praticamente em toda Seção } \mathrm{B} \text {, o } \\
\text { saxofone assume o protagonismo melódico, enquanto o bombardino } \\
\text { executa frases menos sobressalentes, de caráter mais contrapontístico, } \\
\text { exceto pela frase que se inicia no compasso } 45 \text { e que termina em uma } \\
\text { escala descendente de Mi bemol maior, encerrando a parte B em unissono } \\
\text { com o saxofone, que toca a mesma nota (Mi bemol), três oitavas acima } \\
\text { (som real). }\end{array}$ \\
\hline $49-54$ & Transição & $\begin{array}{l}\text { Trecho caracterizado pelo uso de cromatismo, apesar da armadura de } \\
\text { clave com três bemóis. Enquanto o bombardino realiza uma escala } \\
\text { cromática ascendente a partir da nota Mib, o saxofone executa uma } \\
\text { melodia arpejada, onde boa parte dessas notas estão alteradas, ora com } \\
\text { sustenido, ora com bemóis. Como resultado, a angulosidade dessa } \\
\text { melodia forma duas escalas cromáticas simultâneas nos dois extremos do } \\
\text { contomo melódico da melodia executada pelo saxofone. Embora o efeito } \\
\text { sonoro seja bastante consonante, trata-se de uma ponte modulatória para } \\
\text { retomo à tonalidade de Sol menor. }\end{array}$ \\
\hline $55-72$ & $\mathbf{A}^{\prime}$ & $\begin{array}{l}\text { Reapresentação do material temático quase integral. As únicas alterações } \\
\text { dizem respeito à eliminação de um compasso, o que seria a repetição do } \\
\text { compasso 16; mudança no último compasso (c. } 72 \text { ), e, a partir do } \\
\text { compasso } 66 \text { até o compasso } 71 \text {, todas as frases de ambos os instrumentos } \\
\text { estão transpostas para outras alturas, porém, permanecem intactos os } \\
\text { valores rítmicos e a duração das figuras. }\end{array}$ \\
\hline $73-93$ & $\mathrm{C}$ & $\begin{array}{l}\text { Síntese de tudo que foi apresentado com poucas novidades temáticas e } \\
\text { motívicas, exceto para o compasso } 86 \text {, onde o compositor apresenta uma } \\
\text { nova variação rítmica para o Motivo } 3 \text {. Do compasso } 87 \text { até o final, os } \\
\text { dois instrumentos executam frases melódicas similares ritmicamente, } \\
\text { terminando em um crescendo, a partir de um andamento vivo súbito nos } \\
\text { dois últimos compassos. }\end{array}$ \\
\hline
\end{tabular}

Quadro 2: Diálogo Sonoro ao Luar. Estrutura composicional. Fonte: Elaboração própria. 


\title{
Interfaces estilísticas em Diálogo Sonoro ao Luar
}

No que tange aos processos composicionais de Francisco Braga, é consenso entre os pesquisadores afirmar que a contribuição do compositor à cultura musical brasileira é de inestimável valor. Segundo Kiefer (1976), a atividade artística de Braga foi longa e fecunda, "seja como regente de orquestra, como professor, organizador da vida musical e compositor" (KIEFER, 1976, p. 133). Dentro deste contexto, o pesquisador Renato Almeida (1942) caracteriza a obra de Francisco Braga em duas vertentes, "[...] sendo uma como 'tendências gerais', dentro das influências europeias e outra caracterizada com uma 'orientação nativista', refletindo esse esforço para encontrar uma expressão musical que seja o reflexo da nossa realidade" (Almeida, 1942, p. 442).

Em corroboração ao pensamento de Almeida (1942), Kiefer (1976, p. 133) também classifica a produção musical de Francisco Braga em duas vertentes, "[...] uma totalmente independente de sua terra; outra, apresentando elementos nacionalistas", citando Diálogo Sonoro ao Luar como uma das obras mais representativas dessa brasilidade nacionalista de Francisco Braga:

\begin{abstract}
Caberá à musicologia brasileira do futuro a revisão da obra de Francisco Braga. Embora não brilhe pela força criadora, é possível que se encontre, em sua vasta bagagem musical, uma ou outra obra que tenha condições de permanecer no repertório musical brasileiro. Provavelmente restarão peças de cunho "nacionalista", como, talvez, o Diálogo Sonoro ao Luar, para saxofone alto e bombardino, que possui, dentro de uma escritura polifônica, um clima seresteiro tipicamente nosso (KIEFER, 1976, p. 134).
\end{abstract}

Apesar do enaltecimento de Diálogo Sonoro ao Luar por Kiefer (1976), a obra não tem despertado muito interesse em outros pesquisadores que, por sua vez, têm concentrado suas investigações em obras consideradas mais significativas na vasta produção de Francisco Braga.

No que se refere aos aspectos relacionados às interfaces estilísticas presentes em Diálogo Sonoro ao Luar, uma verificação mais aprofundada em relação à manipulação do material harmônico, motívico e temático, fugiria do escopo deste trabalho. O que apresentaremos a seguir, refere-se apenas a apontamentos iniciais de uma espécie de síntese estilística entre a brasilidade e a influência Ars Gallica ${ }^{8}$ refletida nas estruturas melódicas. Sobre essas interfaces estilísticas, Diálogo Sonoro ao Luar notabiliza-se por demonstrar uma espécie de junção entre a brasilidade nacionalista e características da influência Ars Gallica, por intermédio da "claridade, elegância e sutileza, combinando lirismo e precisão na arte da sugestão", elementos bastante comuns nas canções de câmara de Francisco Braga e que refletem essa influência (SOARES, 2015, p. 27).

Acerca da referência às canções de câmara de Francisco Braga, o elemento de

8 Societé Nationale de Musique, sob o mote Ars Gallica (arte francesa), inicialmente teve como propósito defender a música francesa de influência da música alemã (SOARES, 2015, p. 27). 
brasilidade tipifica-se na seresta ao empregar uma melodia de ritmo sincopado. Além da tipificação da seresta nas estruturas motívicas, a célula rítmica, utilizada no acompanhamento pelo eufônio (c. 72-74 e 76-78), permeia sobre uma linha muito tênue, análoga ao maxixe, ao tango brasileiro e à habanera (NASCIMENTO, 2009). Em alguns momentos, remete à canção de câmara denominada Catita (c. 43-47) de Francisco Braga (1905) e, o acompanhamento da Habanera (c. 1-6), pertencente à segunda suíte da ópera Carmem, de Georges Bizet (1887), conforme observados nos excertos da Fig. 18.

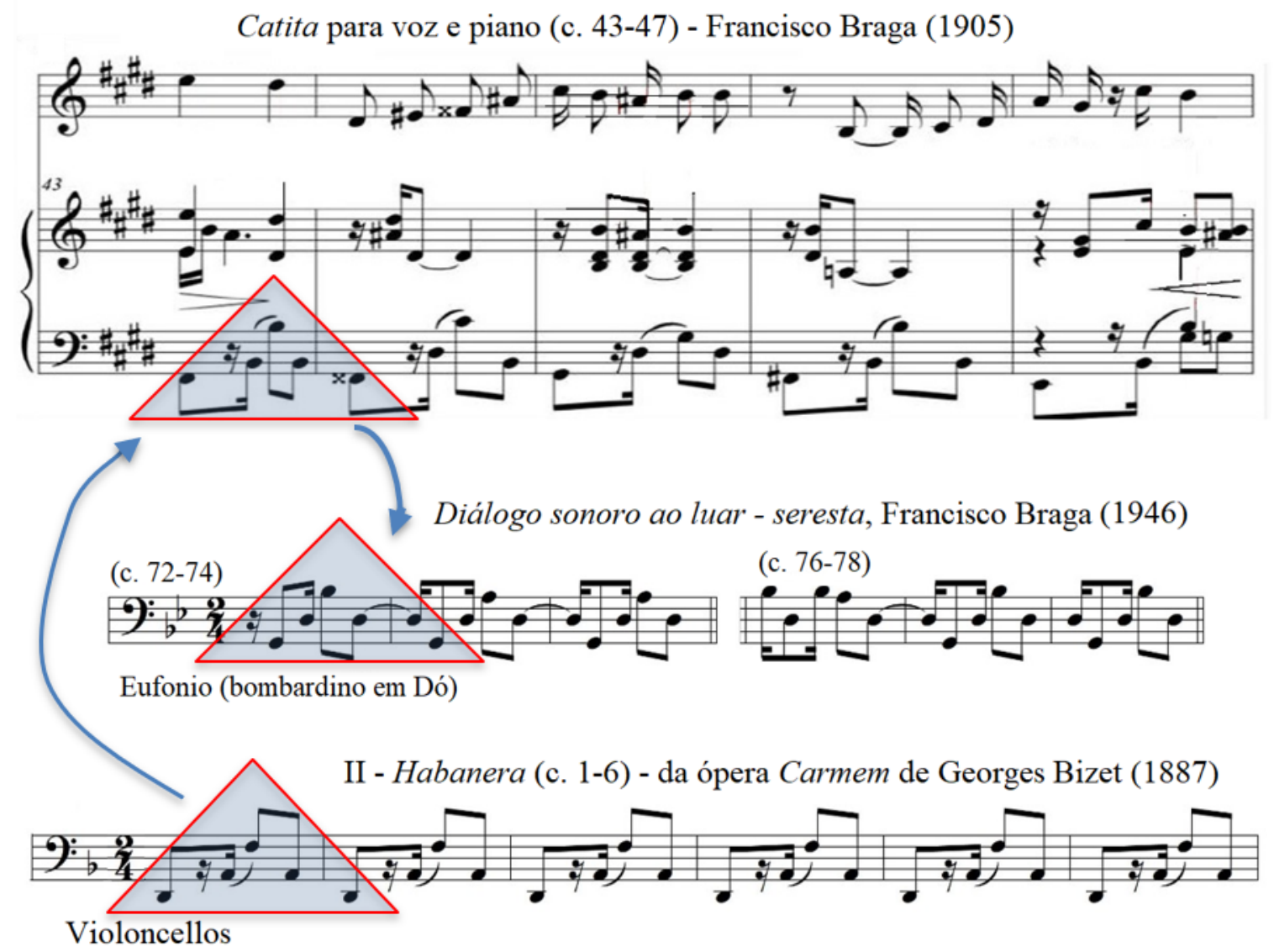

Fig. 18: Excertos das obras Catita - para voz e piano (1905), Diálogo Sonoro ao Luar, (s.d.) de Francisco Braga e Habanera, da ópera Carmem de Georges Bizet (1887). Fonte: Elaboração própria.

No tocante aos elementos de dialogismo e metáfora propostos no título de Diálogo Sonoro ao Luar e como acontece a inter-relação desse enunciado com o discurso musical propriamente dito, observa-se, não somente na partitura, mas também pela audição, o caráter seresteiro que se notabiliza por intermédio da manipulação do material motívico (rítmico e melódico) como eixo de equilíbrio entre o sentido metafórico e a dialética entre dois instrumentos de aspectos construtivos bastante diferentes, mas que se unem por meio de uma escrita exequível viabilizando uma completude harmônica em uma espécie de diálogo onde não há discordâncias. 


\section{Registros fonográficos de Diálogo Sonoro ao Luar}

No que está relacionado a registros fonográficos de Diálogo Sonoro ao Luar, curiosamente, segundo o catálogo da exposição comemorativa do centenário do nascimento de Francisco Braga (1968, p. 56), consta como primeiro registro, a gravação em fita (s.d.), pertencente à Discoteca da Rádio do Ministério da Educação e Cultura, com Giuseppe Sergi (clarineta) e Agobar de Paula (bombardino).

Quanto aos registros fonográficos com os instrumentos originalmente destinados por Francisco Braga, destacam-se as gravações realizadas por Abenata Xavier Padilha (eufônio) e Luiz Gonzaga Carneiro (saxofone alto) no álbum (LP) denominado Recordações de Um Sarau Artístico, de 1984, pela gravadora FENABE e, a gravação no álbum Eufonium Brasileiro de 2008, pelo selo Trilhas Urbanas, com Rodrigo Capistrano no saxofone alto e Fernando Dedos no eufônio (Fig. 19 - 20).

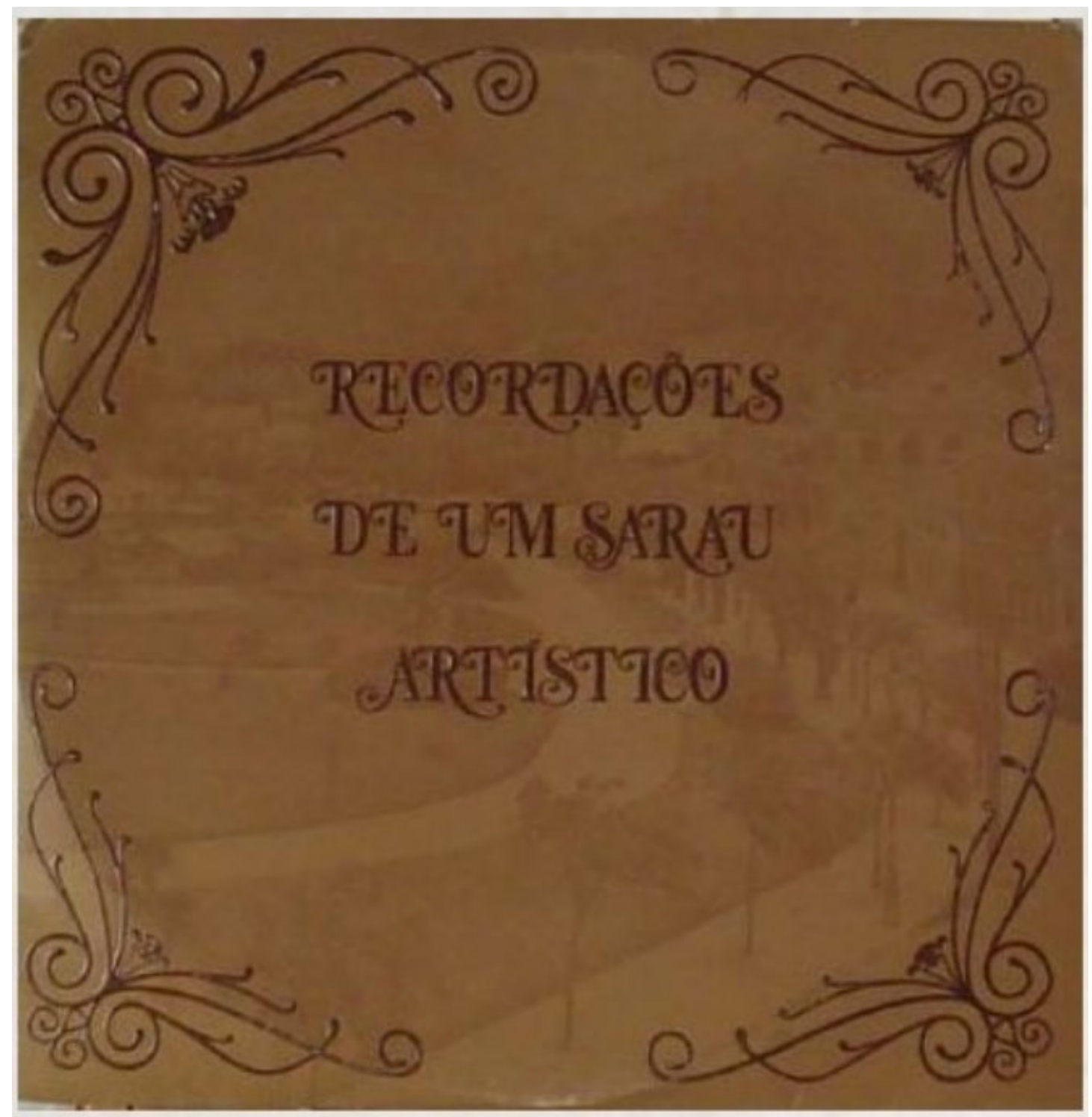

Fig. 19: Capa do LP Recordações de Um Sarau Artístico de 1984. Primeiro registro fonográfico de Diálogo Sonoro ao Luar, de Francisco Braga. Fonte: Recordações de Um Sarau Artístico (1984). 


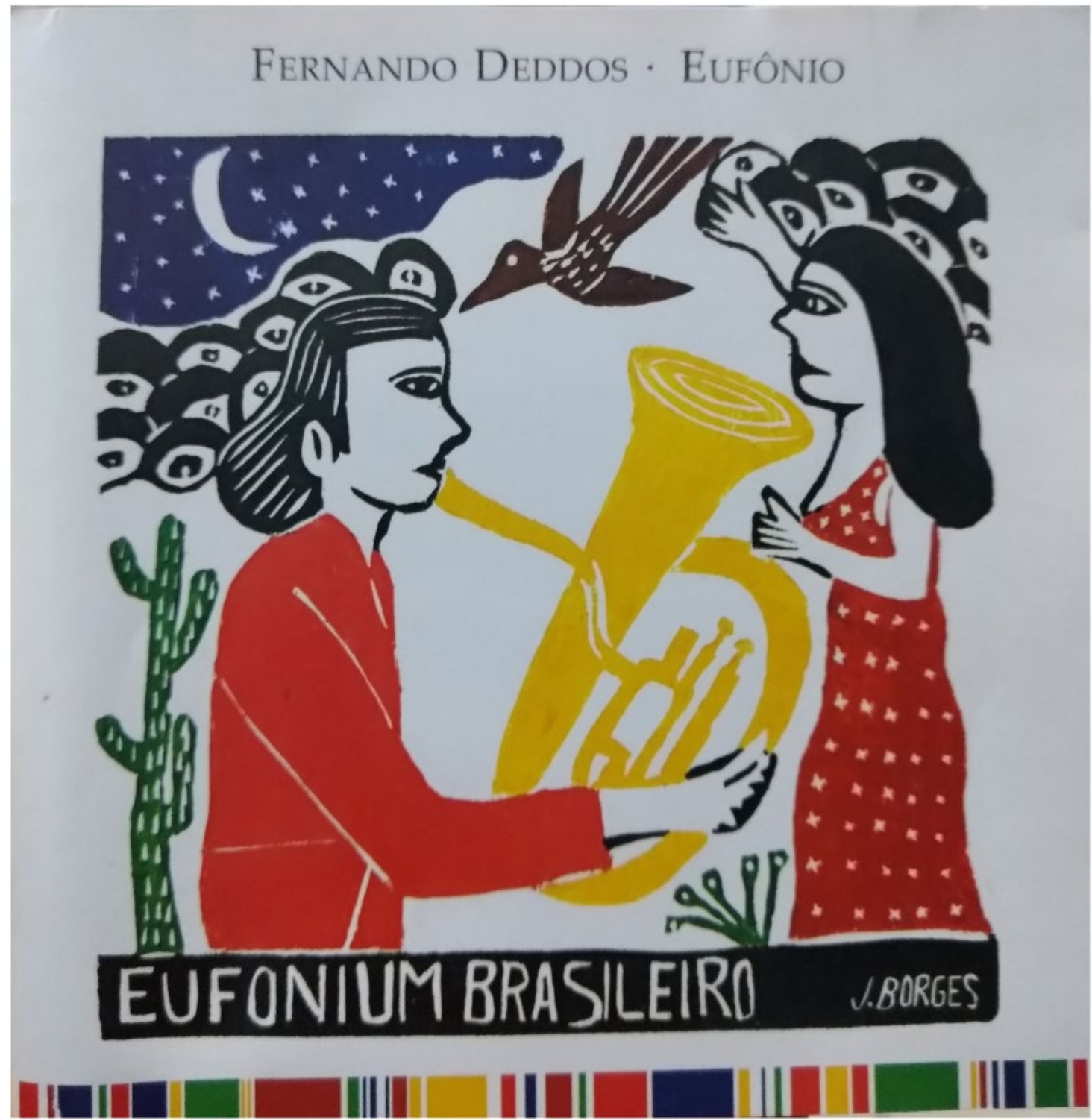

Fig. 20: Capa do CD Eufonium Brasileiro de Fernando Dedos, 2008 - 2 Registro fonográfico de Diálogo Sonoro ao Luar, de Francisco Braga. Fonte: EUFONIUM BRASILEIRO (2008).

Segundo o encarte do álbum Eufonium Brasileiro (2008), de Fernando Deddos a composição para saxofone e eufônio não foi acidental nem um mero experimentalismo. O período de estudos do compositor na Europa pode ter, de alguma forma influenciado muito no que se refere à obra Diálogo Sonoro ao Luar:

Francisco Braga é um dos mais renomados compositores brasileiros da primeira metade do século XX. Com certeza, seu período de estudos de composição na França o fez ver instrumentos como o Saxofone e o Eufônio com outros "ouvidos", pois, vanguarda, e de nome sugestivo, Diálogo Sonoro ao Luar revela soberbamente características líricas e serenas dos dois instrumentos (EUFONIUM BRASILEIRO, 2008, nota do encarte). 
De fato, ao escutarmos a faixa 8, o requinte utilizado por Francisco Braga na manipulação das vozes demonstra domínio e conhecimento acima da média no que diz respeito a itens como tessitura e variedade timbrística dos instrumentos. Braga escolhe para os momentos líricos a melhor região da tessitura de cada instrumento, não apenas do ponto de vista sonoro para o ouvinte, mas, também em relação à execução para os instrumentistas. Não tivemos acesso às demais gravações mencionadas anteriormente (Abenata Xavier Padilha, eufônio, e Luiz Gonzaga Carneiro ao saxofone alto no LP denominado Recordações de Um Sarau Artístico, de 1984, e, a gravação em fita - s.d., pertencente à Rádio do Ministério da Educação e Cultura, com Giuseppe Sergi - clarineta e Agobar de Paula, bombardino), entretanto, em um comparativo entre o registro no álbum Eufonium Brasileiro, de Fernando Deddos (2008), e, as quase uma dezena de gravações da obra disponibilizadas na plataforma YouTube, observando o senso interpretativo do caráter seresteiro empregado no manuseio dos fraseados, afinação e dinâmicas, torna o registro de Fernando Deddos e Rodrigo Capistrano uma referência para aqueles que no futuro se interessarem ao estudo desta obra.

\section{Considerações finais}

Concernente à utilização e à representatividade do saxofone na música brasileira, este estudo aponta para Cantigas e danças dos pretos como uma das obras mais expressivas referentes à utilização do instrumento por um dos grandes compositores da música brasileira da primeira metade do século XX. A importância se dá, não apenas para a comunidade saxofonista, tampouco somente pelo fato de se tratar da primeira participação do instrumento na obra camerística de Francisco Braga, mas por um somatório de coisas, incluindo também, ser esse, o primeiro registro da participação do saxofone na música de câmara brasileira.

Com relação à percepção do significado de Cantigas e danças dos pretos, quanto à independência, notoriedade e exclusividade do instrumento em consideração à atenção recebida de Francisco Braga, essa percepção se amplia ao observarmos que se trata, também, da primeira obra exclusivamente dedicada ao instrumento no contexto da música brasileira de concerto que se tem registro.

No que diz respeito às interfaces estilísticas, conforme argumentado no subitem 3, constatou-se, por intermédio da análise, uma amostra substancial desse modelo de confluência bastante presente na música brasileira, sobretudo na obra de Francisco Braga. Sobre a obra Diálogo Sonoro ao Luar, tida como uma das obras que no futuro, conforme apontou Kiefer (1976, p. 134) (citação na íntegra vide página 23), necessitaria ser revisitada e mais bem estudada, a reflexão que se faz sobre essa colocação de Kiefer, após 44 anos, é que o pedido contido no texto ainda continua muito vivo, apesar do reconhecido esforço de muitos pesquisadores que se debruçam sobre a obra do compositor. Este estudo permitiu notabilizar a existência de lacunas confirmando, em parte, o pouco avanço da musicologia brasileira nesse sentido. 


\section{Referências bibliográficas}

ACERVO DIGITAL CHIQUINHA GONZAGA. Disponível em: www.chiquinhagonzaga. com/acervo. Acesso em: 27 jan. 2021.

ADLER, Samuel. The study of orchestration. 3. ed. New York: W.W. Norton \& Company, 2002.

ALMEIDA, Renato. História da música brasileira. Rio de Janeiro: F. Briguiet \& Comp., 1942.

BIBLIOTECA NACIONAL. Exposição comemorativa do centenário do nascimento de Francisco Braga, 1868-1945. Rio de Janeiro: BIBLIOTECA NACIONAL, 1968.

BOLETIM SUL-AMERICANO DE MUSICOLOGIA. Suplemento Musical. Rio de Janeiro: Irmãos Vitale, 1946. v. Tomo VI. 1 partitura. Saxofone alto e Bombardino.

BRAGA, Francisco. Cantigas e danças dos pretos: d'o contratador dos diamantes. Conjunto de Saxofones. Rio de Janeiro: Casa Guarany, 1905.1 partitura.

BRAGA, Francisco. Diálogo Sonoro ao Luar: seresta. Saxofone alto e Bombardino. Boletin Sul americano de musicologia - Suplemento Musical. Rio de Janeiro: Irmãos Vitale, 1946. v. Tomo VI. 1 partitura.

BRASILIDADE. In: INFOPÉDIA dicionários. Porto: Porto Editora, 2003-2021. Disponível em: https://www.infopedia.pt/dicionarios/lingua-portuguesa-aao/brasilidade. Acesso em: 18 maio 2021.

CANTIGA e Danças dos pretos (d'O Contratador de diamantes), Francisco Braga (1905). [S. l.: s. n.], 2021. 1 vídeo (2 min). Publicado pelo canal José de Carvalho. Disponível em: https://www.youtube.com/watch?v=ddUWLrOpq4E. Acesso em: 27 jan. 2021.

CAZES, H. L. As três fases do maxixe música. Música Popular em Revista, Campinas, v. 6, n. 1, p. 92-108, 2019. DOI: 10.20396/muspop.v6i1.13150. Disponível em: https:// econtents.bc.unicamp.br/inpec/index.php/muspop/article/view/13150. Acesso em: 31 jan. 2021.

CHIQUINHA Gonzaga - Gaúcho (Corta-jaca) (Olinda Allessandrini, piano). [S. l.: s. n.], 2018. 1 vídeo (1 min). Publicado pelo canal Instituto Piano Brasileiro - IPB. Disponível em: https://www.youtube.com/watch?v=T7PIEGSOIKO. Acesso em: 27 jan. 2021.

EUFONIUM Brasileiro. Compositor: Eufônio: Fernando Dedos. Curitiba: Gravadora Trilhas Urbanas, 2008. 1 CD. 
HENRIQUE, Luís. Instrumentos musicais. Lisboa: Fundação Calouste Gulbenkian, 1988.

KIEFER, Bruno. História da música brasileira, dos primórdios ao início do séc. XX. Porto Alegre: Movimento; Brasília; Instituto Nacional do Livro, 1976.

KOSTKA, Stefan; PAYNE, Dorothy. Harmonia Tonal. Traduzido a partir da Sexta edição, de 2008, por Hugo L. Ribeiro, Jamary Oliveira e Ricardo Bordini. Última atualização: 14 abr. 2015.

LOPES, Guilhermina. Onde começa a Música Brasileira? Olhares da Historiografia Musical e da Etnomusicologia. In: SIMPOM, 2., 2012, Rio de Janeiro. Anais [...]. Rio de Janeiro: SIMPOM, 2012. p. 737-746. Disponível em: http://www.seer.unirio.br/index. php/simpom/article/viewFile/2498/1827. Acesso em: 27 jan. 2021.

MACEDO, Vinícius. Os primeiros manuscritos brasileiros para conjuntos de saxofones de Francisco Braga: a possível origem de uma prática musical na Belle Époque do Rio de Janeiro. In: CONGRESSO DA ANPPOM, 26., 2019, Pelotas. Anais [...]. Pelotas: ANPPOM, 2019. p. 1-10. Disponivel em: http://www.anppom.com.br/congressos/ index.php/29anppom/29CongrAnppom/paper/viewFile/5747/2254. Acesso em: 4 abr. 2020.

NASCIMENTO, Antonio Adriano Blanc. A influência da habanera nos tangos de Ernesto Nazareth (1863-1934). Bebedouro: Albergráfica, 2009.

OLIVEIRA, Janne Gonçalves de. A biografia de Francisco Braga: um recorte em torno do Hino do Brasil. In: CONGRESSO DA ANPPOM, 26., 2019, Pelotas. Anais [...]. Pelotas: ANPPOM, 2019. p. 1-8. Disponível em: http://www.anppom.com.br/congressos/index. php/29anppom/29CongrAnppom/paper/viewFile/5885/2220. Acesso em: 5 abr. 2020.

OLIVEIRA, José de Carvalho. Fantasia para saxofone soprano e pequena orquestra, de Villa-Lobos (1948): aspectos contextuais e análise estrutural do primeiro movimento. 2019. Dissertação (Mestrado em Musicologia) Escola de Comunicações e Artes, Universidade de São Paulo, São Paulo, 2019. Disponível em: https://teses.usp.br/teses/ disponiveis/27/27157/tde-06092019-115619/pt-br.php. Acesso em: 5 abr. 2020.

VITO, Milton. Entrevista concedida a José de Carvalho Oliveira em 27 jan. 2021. São Paulo, EMESP. Registro em mp3.

PICCHI, Achille Guido. As Serestas de Heitor Villa-Lobos = um estudo de análise, textomúsica e pianismo para uma interpretação. 2010. 356 p. Tese (Doutorado) Instituto de Artes, Universidade Estadual de Campinas, Campinas, 2010. Disponível em: http:// www.repositorio.unicamp.br/handle/REPOSIP/283932. Acesso em: 23 jan. 2021. 
RECORDAÇÕES de um sarau artístico. [S. l.]: FENABE, 1984. 1 LP. Catálogo FENABE 108.

SERESTEIRO. In: Michaelis: Dicionário Brasileiro da Língua Portuguesa. Disponível em: https://michaelis.uol.com.br/palavra/A8yEV/seresteiro/\#: :text=Que\%20ou\%20 quem\%20canta\%20m\%C3\%BAsicas,ETIMOLOGIA\%20der\%20de\%20seresta\%2Beiro. Acesso em: 24 maio 2021.

SOARES, Márcia Aparecida. As canções de Francisco Braga: análise estilística e interpretação. 2015. Dissertação (Mestrado em Artes) - Instituto de Artes da Universidade de Uberlândia, Uberlândia, 2015. Disponível em: https://repositorio.ufu. br/handle/123456789/12362. Acesso em: 18 maio 2021.

SOUZA, Valéria Gomes de. A seresta e a serenata nas cidades de Conservatória e Niterói, no Estado do Rio de Janeiro. 2010. 135 p. Dissertação (Mestrado em Música) - Programa de Pós-Graduação em Música, Centro de Letras e Artes, Universidade Federal do Estado do Rio de Janeiro, 2010. Disponível em: http://www.repositorio-bc. unirio.br:8080/xmlui/handle/unirio/11466. Acesso em: 18 maio 2021.

UNVERRICHT, Hubert; EISEN, Cliff. The new Grove dictionary of Music and Musicians. 2. ed. 2001. Disponível em http://www.oxfordmusiconline.com. Acesso em: 24 jan. 2021.

VOLPE, M. A. Período romântico brasileiro: alguns aspectos da produção camerística. Revista Música, v. 5, n. 2, p. 133-151, 1994. DOI: 10.11606/rm.v5i2.55078. Disponível em: https://www.revistas.usp.br/revistamusica/article/view/55078. Acesso em: 31 jan. 2021. 